\title{
Unusual silicate mineralization in fumarolic sublimates of the Tolbachik volcano, Kamchatka, Russia - Part 2: Tectosilicates
}

\author{
Nadezhda V. Shchipalkina ${ }^{1}$, Igor V. Pekov ${ }^{1}$, Natalia N. Koshlyakova ${ }^{1}$, Sergey N. Britvin ${ }^{2,3}$, \\ Natalia V. Zubkova ${ }^{1}$, Dmitry A. Varlamov ${ }^{4}$, and Eugeny G. Sidorov ${ }^{5}$ \\ ${ }^{1}$ Faculty of Geology, Moscow State University, Vorobievy Gory, 119991 Moscow, Russia \\ ${ }^{2}$ Department of Crystallography, St Petersburg State University, \\ University Embankment 7/9, 199034 St. Petersburg, Russia \\ ${ }^{3}$ Kola Science Center of Russian Academy of Sciences, Fersman Str. 14, 184200 Apatity, Russia \\ ${ }^{4}$ Institute of Experimental Mineralogy, Russian Academy of Sciences, \\ Akademika Osypyana ul., 4, 142432 Chernogolovka, Russia \\ ${ }^{5}$ Institute of Volcanology and Seismology, Far Eastern Branch of Russian Academy of Sciences, \\ Piip Boulevard 9, 683006 Petropavlovsk-Kamchatsky, Russia
}

Correspondence: Nadezhda V. Shchipalkina (estel58@yandex.ru)

Received: 19 June 2019 - Accepted: 1 November 2019 - Published: 29 January 2020

\begin{abstract}
This second of two companion articles devoted to silicate mineralization in fumaroles of the Tolbachik volcano (Kamchatka, Russia) reports data on chemistry, crystal chemistry and occurrence of tectosilicates: sanidine, anorthoclase, ferrisanidine, albite, anorthite, barium feldspar, leucite, nepheline, kalsilite, sodalite and hauyne. Chemical and genetic features of fumarolic silicates are also summarized and discussed. These minerals are typically enriched with "ore" elements (As, $\mathrm{Cu}, \mathrm{Zn}, \mathrm{Sn}, \mathrm{Mo}, \mathrm{W}$ ). Significant admixture of $\mathrm{As}^{5+}$ (up to $36 \mathrm{wt} \% \mathrm{As}_{2} \mathrm{O}_{5}$ in sanidine) substituting $\mathrm{Si}$ is the most characteristic. Hauyne contains up to $4.2 \mathrm{wt} \%$ $\mathrm{MoO}_{3}$ and up to $1.7 \mathrm{wt} \% \mathrm{WO}_{3}$. All studied silicates are hydrogen-free, including mica and amphiboles which are F-rich. Iron-bearing minerals contain only $\mathrm{Fe}^{3+}$ due to strongly oxidizing formation conditions. In Tolbachik fumaroles, silicates were formed in the temperature range $500-800{ }^{\circ} \mathrm{C}$ as a result of direct deposition from the gas phase (as volcanic sublimates) or gas-rock interactions. The zonation in distribution of major silicate minerals observed in a vertical section of the Arsenatnaya fumarole, from deep (the hottest) to upper parts is diopside + forsterite + enstatite + andradite $\rightarrow$ diopside $\rightarrow$ fluorophlogopite + diopside $\rightarrow$ sanidine + fluorophlogopite $\rightarrow$ sanidine. This is in agreement with volatilities of major species-defining metals in volcanic gases. From a crystal-chemical viewpoint, this series corresponds to the following sequence of crystallization of minerals with temperature decrease: nesosilicates $\rightarrow$ inosilicates $\rightarrow$ phyllosilicates $\rightarrow$ tectosilicates.
\end{abstract}

\section{Introduction}

This is the second paper of the pair of articles devoted to the silicate mineralization from fumaroles of the Tolbachik volcano (Kamchatka, Russia). In the first paper, Part 1 (Shchipalkina et al., 2020b), we characterized experimental details, presented the general information on the Tolbachik fumaroles containing silicate minerals, reported data on the diversity of fumarolic silicates and their chemical features, and described neso-, cyclo-, ino- and phyllosilicates.

In this paper we characterize tectosilicates (tectoaluminosilicates). The tectosilicates from the studied Tolbachik fumaroles belong to the well-known structural types (archetypes), namely feldspars and feldspathoids. There are sanidine, anorthoclase, ferrisanidine and plagioclases belonging to the anorthite-andesine series, barium feldspar of the celsian-anorthoclase series, and nepheline, kalsilite, 
leucite, hauyne and sodalite. They were crystallized directly from fumarolic gas as sublimates, or, more probably, formed as a result of interactions between hot gas and basalt scoria from walls of fumarolic vents. In the active fumaroles Arsenatnaya and Yadovitaya, tectosilicates, like other fumarolic minerals, occur as well-shaped crystals in cavities and cracks. They overgrow exhalative arsenates, sulfates, halides and oxides or form close intergrowths with them. Tectosilicates also replace basalt scoria. Both the morphological evidence and the significant admixture of ore components (As, $\mathrm{Cu}, \mathrm{Zn}, \mathrm{Mo}, \mathrm{W}$ ) clearly indicate the fumarolic origin of these minerals (Part 1).

Besides the characterization of tectosilicates, this paper contains discussion and conclusions concerning silicate mineralization in the Tolbachik fumaroles.

\section{Characterization of tectosilicates}

\subsection{Feldspars}

Feldspars are the greatest in abundance and have the largest species and chemical diversity of silicates formed in the Tolbachik fumaroles. The fumarolic feldspars belong to two series, $\mathrm{K}-\mathrm{Na}$ feldspars and plagioclases ( $\mathrm{Ca}-\mathrm{Na}$ series) (Table 1; Fig. 1a).

$\mathrm{K}-\mathrm{Na}$ feldspars form a continuous solid-solution series between sanidine and anorthoclase here. According to the classification of alkaline feldspars suggested by Deer et al. (2001) and used at present, a field of monoclinic sanidine includes $\mathrm{K}$ sanidine within the limits of $\mathrm{Or}_{100}-\mathrm{Or}_{70}$ and $\mathrm{Na}$ sanidine as well as $\mathrm{Or}_{70}-\mathrm{Or}_{40}$ (Or isorthoclase, $\mathrm{K}\left[\mathrm{AlSi}_{3} \mathrm{O}_{8}\right]$ ). The solid solution extends there from the end-member $\mathrm{K}\left[\mathrm{AlSi}_{3} \mathrm{O}_{8}\right]$ to the composition $\quad\left(\mathrm{Na}_{0.84} \mathrm{~K}_{0.13} \mathrm{Ca}_{0.03}\right)_{\sum 1.00}\left[\left(\mathrm{Si}_{2.56} \mathrm{Al}_{1.29} \mathrm{As}_{0.15}^{5+} \mathrm{P}_{0.02}\right.\right.$ $\left.\mathrm{Fe}_{0.01}^{3+}\right)_{\sum 4.03} \mathrm{O}_{8}$ ] (Fig. 1a).

Sanidine is widespread in active fumaroles of the second scoria cone of the Northern Breakthrough of the Great Tolbachik Fissure Eruption 1975-1976 (NB GTFE), especially in Yadovitaya and Arsenatnaya, as well as in extinct paleofumaroles of Mountain 1004. In the Arsenatnaya fumarole it is the main silicate phase of Zone IV and zones enriched with alluaudite-group arsenates (Zones $\mathrm{Va}$ and $\mathrm{Vb}$ ). Sanidine typically occurs as prismatic, acicular, tabular or wedgelike crystals up to $0.5 \mathrm{~mm}$ long and up to $0.1 \mathrm{~mm}$ thick with well-developed faces $\{110\},\{010\},\{001\}$ and $\{021\}$. Skeletal, case-like crystals are also common. Sanidine crystals are usually combined in sheaf- or bush-like clusters, rosettes, spherulites, open-work aggregates or crystal crusts covering or replacing basalt scoria (Fig. 2). These crusts are up to several square metres in area and up to $0.5 \mathrm{~cm}$ thick. Sanidine is closely associated with several dozen fumarolic minerals including hematite, tenorite, halite, sylvite, and numerous sulfates and arsenates (Fig. 2).
The framework composition is the most intriguing chemical feature of Tolbachik sanidine. In particular, this silicate forms a continuous solid solution with the arsenate feldspar filatovite with the simplified formula $\mathrm{K}\left[(\mathrm{Al}, \mathrm{Zn})_{2}(\mathrm{As}, \mathrm{Si})_{2} \mathrm{O}_{8}\right]$. This mineral was first discovered in fumaroles of the second scoria cone of the NB GTFE by Vergasova et al. (2004). However, chemical variations in filatovite and an isomorphous relationship with other feldspars have not been systematically studied before our work. Selected analyses of members of this solid-solution series are shown in Table 1. The chemical composition of tetrahedrally coordinated components is displayed in Fig. 1b. The framework composition of feldspars belonging to the sanidine-filatovite solid-solution series varies from $\left[\mathrm{AlSi}_{3} \mathrm{O}_{8}\right.$ ] to $\left[\mathrm{Al}_{1.68} \mathrm{As}_{1.33}^{5+} \mathrm{Si}_{0.70} \mathrm{Zn}_{0.15} \mathrm{Fe}_{0.07}^{3+} \mathrm{Cu}_{0.07} \mathrm{O}_{8}\right.$ ], which corresponds to the following concentration ranges of chalcophile components as percentages of weight: $\mathrm{As}_{2} \mathrm{O}_{5}$ 0-43.7, $\mathrm{ZnO} 0-3.7$ and $\mathrm{CuO} 0-1.6$. In the aluminosilicate part of the series (with $\mathrm{Si}>\mathrm{As}$ in atomic proportions), the framework composition varies from $\left[\mathrm{AlSi}_{3} \mathrm{O}_{8}\right]$ to $\left[\mathrm{Al}_{1.92} \mathrm{Si}_{1.02} \mathrm{As}_{1.00}^{5+} \mathrm{Fe}_{0.03}^{3+} \mathrm{P}_{0.04}^{5+} \mathrm{O}_{8}\right]\left(\mathrm{As}_{2} \mathrm{O}_{5} 0-36.0 \mathrm{wt} \%\right)$. Noteworthily, filatovite with As content higher than 1.20 atoms per formula unit (apfu) always contains a significant impurity of the divalent transition metals $\mathrm{Zn}(0.05-$ $0.20 \mathrm{apfu}) \mathrm{and} / \mathrm{or} \mathrm{Cu}(0.03-0.09 \mathrm{apfu})$ while the samples with lower As content are commonly $\mathrm{Zn}$ - and $\mathrm{Cu}$-poor.

Fumarolic sanidine was examined using Raman spectroscopy (Fig. 3). The spectra of our samples match with the sanidine spectrum published by Freeman et al. (2008) and clearly differ from the Raman spectra of orthoclase and microcline due to the absence of (1) a well-resolved triplet in the $450-520 \mathrm{~cm}^{-1}$ region, (2) split bands in the 150-200 and $280-285 \mathrm{~cm}^{-1}$ regions, and (3) resolved bands in the 745$820 \mathrm{~cm}^{-1}$ region.

The powder X-ray diffraction (XRD) patterns of sanidine samples from Arsenatnaya and Yadovitaya are close to the data calculated by Ferguson et al. (1991). In particular, the reflections $(d, \AA$ A- $I, \%$; intensities $I$ are given for $\operatorname{Co} K \alpha) 1 \overline{1} 1$ (5.926-5), $1 \overline{3} 0$ (3.705-46) and $1 \overline{3} 1$ (2.954-41) inherent for microcline (Finney and Bailey, 1977) are absent for our samples.

The crystal structure of several sanidine samples from Arsenatnaya and Yadovitaya was studied using the Rietveld method. Unit-cell parameters and $T-\mathrm{O}$ distances in $T(1) \mathrm{O}_{4}$ and $T(2) \mathrm{O}_{4}$ tetrahedra are given in Table 2. For verification of our data obtained with the Rietveld method, we also calculated the content of $\mathrm{Al}$ at both $T(1)$ and $T(2)$ sites using the procedure suggested by Stewart and Wright (1974) and Kroll and Ribbe (1987). It is based on the regression equation $2 t_{1}=\left(b-24.8095+74.9054 c^{*}\right) /\left(-3.3261+19.5102 c^{*}\right)$ in which $2 t_{1}$ is the doubled content of $\mathrm{Al}$ at the $T(1)$ site; $c^{*}=a b \sin \gamma / V$, where $a, b$ and $\gamma$ are unit-cell parameters. The results of these calculations show that $\mathrm{Al}$ content at the $T 1$ site in our samples varies from 0.51 to 0.55 apfu (Table 2), which corresponds to sanidine. Details of the crystal struc- 


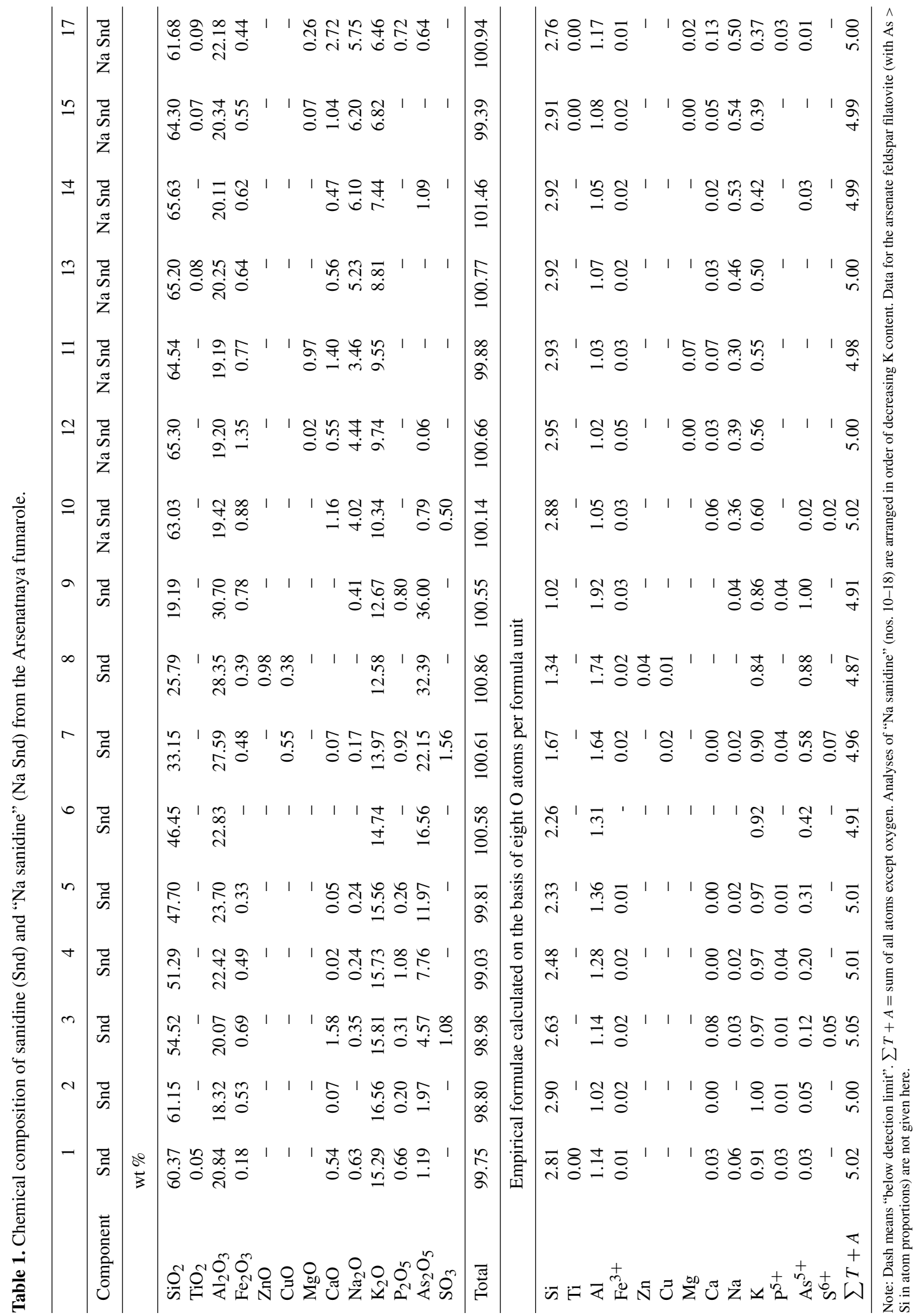



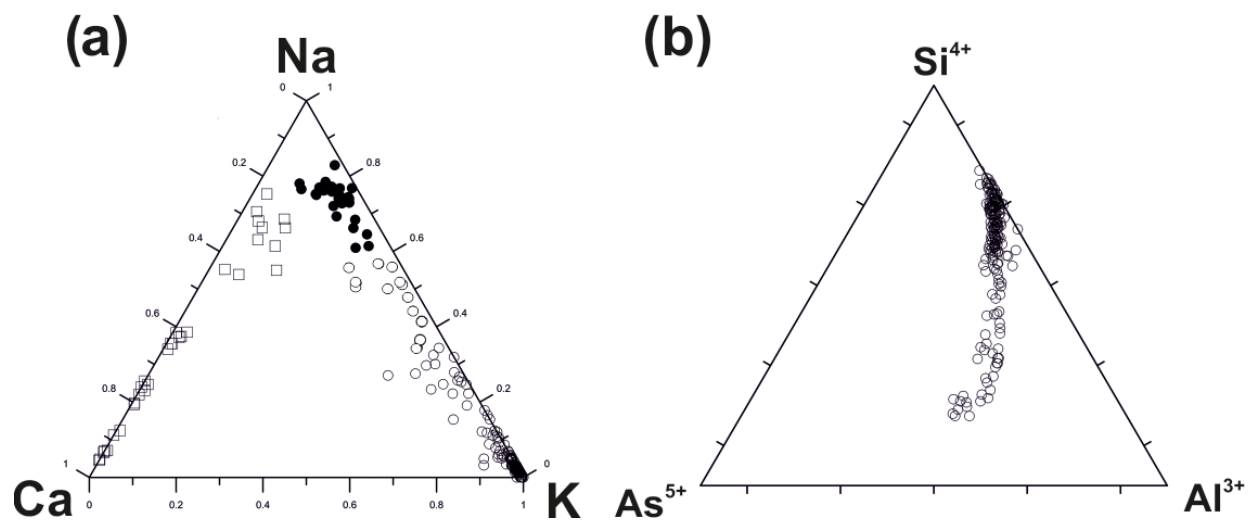

Figure 1. Ratios of major extra-framework cations in fumarolic feldspars from the Arsenatnaya fumarole: $\bigcirc$ - sanidine (including Na sanidine within the limits $\mathrm{Or}_{70}-\mathrm{Or}_{40}$, according to classification by Deer et al. (2001), $\bullet-$ anorthoclase $\left(\mathrm{Or}_{40}-\mathrm{Or}_{90}\right)$, $\square-$ plagioclases (andesine, labradorite, bytownite and anorthite) (a); ratios of major tetrahedrally coordinated components in sanidine-filatovite series from the Arsenatnaya fumarole (b).
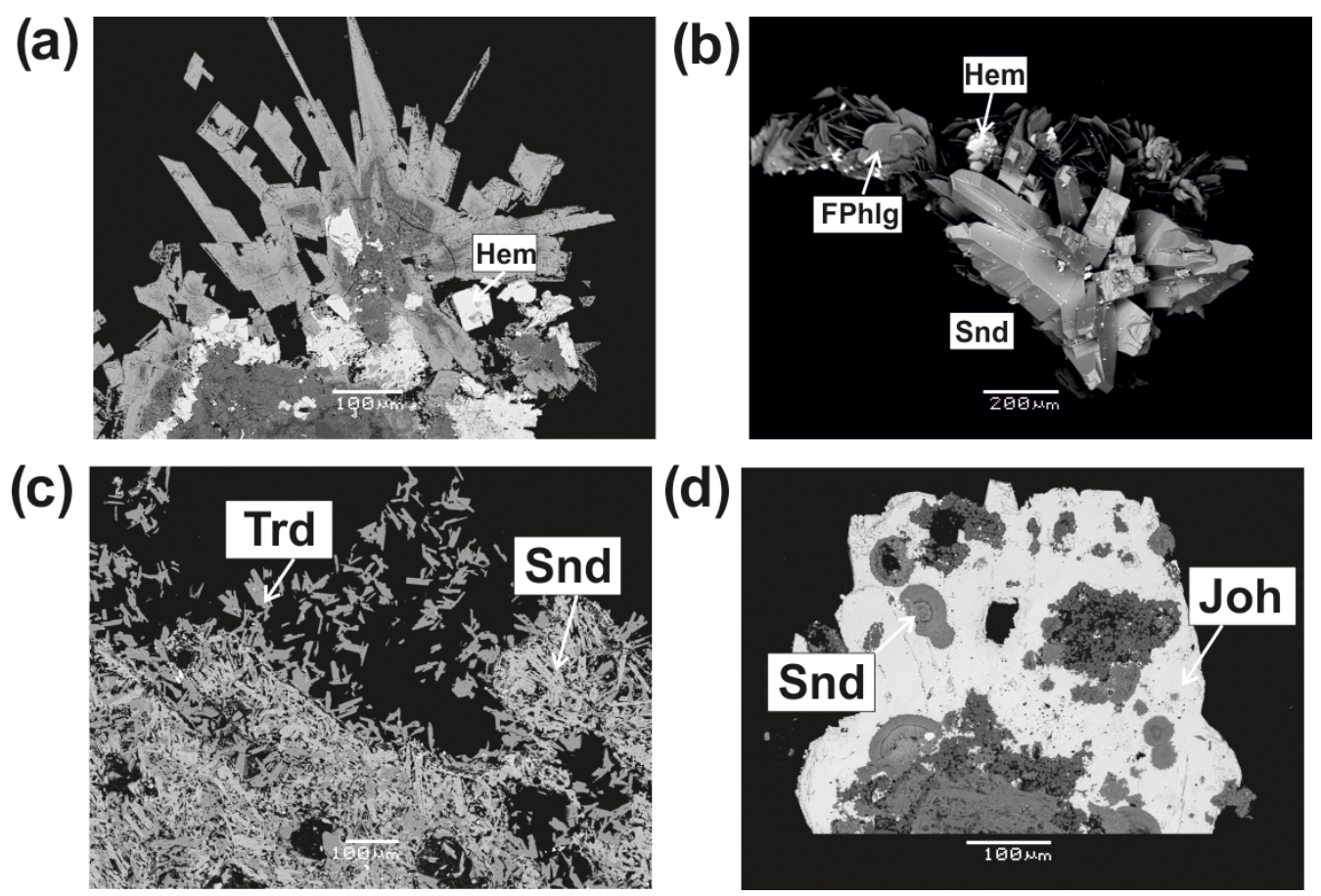

Figure 2. As-bearing sanidine from the Arsenatnaya fumarole: spear-like zoned crystals with hematite (Hem), polished section (a); wellshaped twinned crystals with fluorophlogopite (FPhlg) and hematite (Hem) (b); open-work aggregates of As-bearing sanidine with tridymite (Trd) (c); spherulites of As-bearing sanidine embedded in johillerite (Joh) (d). Backscattered electron (BSE) images.

ture of potassic feldspars belonging to the sanidine-filatovite series from the Arsenatnaya fumarole are addressed in a dedicated paper (Shchipalkina et al., 2020a).

Ferrisanidine, an analogue of sanidine with $\mathrm{Fe}^{3+}$ instead of $\mathrm{Al}$, the new mineral recently discovered by us in the Arsenatnaya fumarole (Shchipalkina et al., 2019). It occurs in association with aegirine, hematite, cassiterite, sylvite, halite, johillerite, badalovite and arsmirandite. This feldspar forms porous crusts up to $0.1 \mathrm{~mm}$ across and up to $20 \mu \mathrm{m}$ thick.
The empirical formula of ferrisanidine based on $8 \mathrm{O}$ apfu is $\left(\mathrm{K}_{0.97} \mathrm{Na}_{0.03}\right)_{\sum 1.00}\left[\left(\mathrm{Si}_{3.03} \mathrm{Fe}_{0.94}^{3+} \mathrm{Al}_{0.02}\right)_{\sum 0.99} \mathrm{O}_{8}\right]$. Determination of its crystal structure with the Rietveld method revealed monoclinic symmetry and a sanidine-like, disordered $\mathrm{Si} / \mathrm{Fe}^{3+}$ distribution at tetrahedral sites of the framework. The unit-cell parameters are $a=8.678(4), b=13.143(8) \AA$, $c=7.337(5) \AA, \beta=116.39(8)^{\circ}$ and $V=749.6(9) \AA^{3}$, and final $R$ factors are $R_{\mathrm{p}}=0.0053, \quad R_{\mathrm{wp}}=0.0075, \quad R_{1}=$ 
Table 2. Unit-cell parameters and $T-\mathrm{O}(T=\mathrm{Si}, \mathrm{Al}, \mathrm{As})$ distances (in ångströms) in the crystal structure of sanidine from active fumaroles Arsenatnaya and Yadovitaya and ancient fumarole at the Mountain 1004.

\begin{tabular}{|c|c|c|c|}
\hline Locality & Arsenatnaya fumarole & Yadovitaya fumarole & Mountain 1004 \\
\hline Framework composition & {$\left[\mathrm{Al}_{1.14} \mathrm{Si}_{2.79} \mathrm{As}_{0.09}^{5+} \mathrm{O}_{8}\right]$} & {$\left[\mathrm{Al}_{1.14} \mathrm{Si}_{2.81} \mathrm{As}_{0.03}^{5+} \mathrm{P}_{0.02}^{5+} \mathrm{O}_{8}\right]$} & {$\left[\mathrm{Al}_{1.08} \mathrm{Si}_{2.92} \mathrm{O}_{8}\right]$} \\
\hline$a, \AA$ & $8.6283(8)$ & $8.6204(6)$ & $8.5986(2)$ \\
\hline$b, \AA$ & 13.0667(12) & $13.0929(9)$ & $13.06942(3)$ \\
\hline$c, \AA$ & 7.2019(6) & $7.2085(6)$ & 7.1933(2) \\
\hline$\beta$ & $116.010(6)$ & $115.957(4)$ & $115.97(2)$ \\
\hline \multirow[t]{2}{*}{$V, \AA^{3}$} & $729.73(12)$ & $731.52(9)$ & 726.97(3) \\
\hline & Rietveld refinement detai & & \\
\hline$R_{\mathrm{p}}, R_{\mathrm{wp}}$ & $0.0054,0.0072$ & $0.0063,0.0085$ & - \\
\hline$R_{1}, w R_{2}$ & $0.0126,0.0180$ & $0.0151,0.0222$ & - \\
\hline \multirow[t]{2}{*}{ GOF } & 2.54 & 2.99 & - \\
\hline & $T-\mathrm{O}$ distance in $T(1)$ tetr & ahedron & \\
\hline$T(1)-\mathrm{O} 1$ & $1.661(3)$ & $1.646(1)$ & - \\
\hline$T(1)-\mathrm{O} 3$ & 1.641(3) & $1.618(1)$ & - \\
\hline$T(1)-\mathrm{O} 4$ & $1.645(3)$ & $1.679(1)$ & - \\
\hline$T(1)-\mathrm{O} 5$ & $1.647(4)$ & $1.641(1)$ & - \\
\hline \multirow[t]{2}{*}{ Average } & $\langle 1.649\rangle$ & $\langle 1.646\rangle$ & - \\
\hline & $T-\mathrm{O}$ distance in $T(2)$ tetr & ahedron & \\
\hline$T(2)-\mathrm{O} 2$ & $1.643(3)$ & $1.663(1)$ & - \\
\hline$T(2)-\mathrm{O} 3$ & $1.628(2)$ & $1.614(1)$ & - \\
\hline$T(2)-\mathrm{O} 4$ & $1.652(3)$ & $1.677(1)$ & - \\
\hline$T(2)-\mathrm{O} 5$ & $1.648(4)$ & $1.670(1)$ & - \\
\hline Average & $\langle 1.643\rangle$ & $\langle 1.656\rangle$ & - \\
\hline $2 t_{1}^{*}$ & 0.55 & 0.51 & 0.53 \\
\hline
\end{tabular}

0.0543 and $w R_{2}=0.0681$. The crystal-chemical formula is $\left.\mathrm{K}^{T(1)}\left(\mathrm{Si}_{0.7} \mathrm{Fe}_{0.3}\right)_{2}^{T(2)}\left(\mathrm{Si}_{0.7} \mathrm{Fe}_{0.3}\right)_{2} \mathrm{O}_{8}\right]$.

Anorthoclase, (K, Na) $\left[\mathrm{AlSi}_{3} \mathrm{O}_{8}\right]-(\mathrm{Na}, \mathrm{K})\left[\mathrm{AlSi}_{3} \mathrm{O}_{8}\right]$, occurs in Zones VIa and VIb of the Arsenatnaya fumarole in association with diopside, forsterite, anhydrite and hematite. Thin diopside-anorthoclase crystal crusts cover basalt scoria. Anorthoclase also forms tiny (up to $15 \mu \mathrm{m}$ ) crystals in cavities (Fig. 4). Selected chemical analyses of anorthoclase from the Arsenatnaya fumarole are presented in Table 3. Its composition corresponds to the range $\mathrm{Or}_{15} \mathrm{Ab}_{85}-\mathrm{Or}_{37} \mathrm{Ab}_{63}$ (Ab is albite component $\mathrm{NaAlSi}_{3} \mathrm{O}_{8}$ ) (Fig. 1a) and contains up to $6.3 \mathrm{wt} \% \mathrm{As}_{2} \mathrm{O}_{5}$.

Powder XRD data show that fumarolic anorthoclase is triclinic with the unit-cell parameters $a=8.20(3), b=$ $12.87(3), c=7.10(2) \AA, \alpha=91.7(1), \beta=116.1(2), \gamma=$ $90.2(2)^{\circ}$ and $V=673.2(5) \AA^{3}$.

Plagioclases from the Arsenatnaya fumarole include two mineral species, albite (variety: andesine) and the more common anorthite (varieties: labradorite, bytownite and anorthite sensu stricto), containing up to $1.4 \mathrm{wt} \% \mathrm{As}_{2} \mathrm{O}_{5}$ (Table 3). They form thin cavernous crusts covering basalt scoria
(Fig. 5) in Zones VIa and VIb. Plagioclases are rare compared to $\mathrm{K}-\mathrm{Na}$ feldspars.

Barium-rich feldspars of the celsian-anorthoclase series occur in Zone VI of the Arsenatnaya fumarole as tiny (less than $10 \mu \mathrm{m}$ ) inclusions in diopside and hematite (Fig. 4c). Small size and close intergrowths with associated minerals hampered exact identification of these minerals. The representative empirical formulae of $\mathrm{Na}-$ and $\mathrm{Ba}$-dominant samples based on eight $\mathrm{O}$ atoms are $\left(\mathrm{Na}_{0.31} \mathrm{Ba}_{0.29} \mathrm{~K}_{0.27} \mathrm{Sr}_{0.12}\right)_{\sum 0.99}\left[\left(\mathrm{Si}_{2.53} \mathrm{Al}_{1.49}\right)_{\sum 4.02} \mathrm{O}_{8}\right]$ and $\quad\left(\mathrm{Ba}_{0.57} \mathrm{Sr}_{0.10} \mathrm{~K}_{0.12} \mathrm{Na}_{0.11} \mathrm{Ca}_{0.07}\right)_{\sum 0.97}\left[\left(\mathrm{Si}_{2.17} \mathrm{Al}_{1.81}\right.\right.$ $\left.\mathrm{Fe}_{0.06}^{3+}\right)_{\sum 4.04} \mathrm{O}_{8}$ ], respectively.

\subsection{Feldspathoids}

Nepheline is a very rare mineral which was detected only in one sample. It forms roundish inclusions in a porous mass of sanidine which replaces basalt scoria (Fig. 6). The chemical composition (Table 4) corresponds to the empirical formula $\mathrm{K}_{0.25} \mathrm{Na}_{3.52}\left[\left(\mathrm{Si}_{4.21} \mathrm{Al}_{3.78} \mathrm{Fe}_{0.02}^{3+}\right){ }_{\sum 8.00} \mathrm{O}_{16}\right]$. Thus, this nepheline is sodium- and silica-rich. 
Table 3. Chemical composition of anorthoclase (Anrth), barium feldspar (Ba Fs) and plagioclases (Pl) from the Arsenatnaya fumarole.

\begin{tabular}{|c|c|c|c|c|c|c|c|c|c|c|c|c|c|}
\hline & 1 & 2 & 3 & 4 & 5 & 6 & 7 & 8 & 9 & 10 & 11 & 12 & 13 \\
\hline \multirow[t]{2}{*}{ Component } & Anrth & Anrth & Anrth & Anrth & Anrth & $\mathrm{Ba} F s$ & $\mathrm{Ba} F s$ & $\mathrm{Pl}$ & $\mathrm{Pl}$ & $\mathrm{Pl}$ & $\mathrm{Pl}$ & $\mathrm{Pl}$ & $\mathrm{Pl}$ \\
\hline & wt $\%$ & & & & & & & & & & & & \\
\hline $\mathrm{SiO}_{2}$ & 63.56 & 56.10 & 62.27 & 64.57 & 60.05 & 38.81 & 50.26 & 62.71 & 61.24 & 59.02 & 51.39 & 46.63 & 44.48 \\
\hline $\mathrm{TiO}_{2}$ & 0.43 & 0.12 & 0.70 & 0.15 & - & - & - & 0.06 & - & 0.24 & - & - & 0.12 \\
\hline $\mathrm{Al}_{2} \mathrm{O}_{3}$ & 22.23 & 23.88 & 20.61 & 21.15 & 23.30 & 27.43 & 25.12 & 21.75 & 24.29 & 16.61 & 32.86 & 35.21 & 36.73 \\
\hline $\mathrm{Fe}_{2} \mathrm{O}_{3}$ & 1.21 & 0.26 & 1.31 & 0.50 & 0.67 & 1.32 & - & 0.89 & 0.37 & 3.68 & 0.20 & 0.68 & 0.67 \\
\hline $\mathrm{MgO}$ & - & - & - & - & - & - & - & 0.53 & - & 1.22 & - & - & - \\
\hline $\mathrm{CaO}$ & 2.79 & 0.62 & 1.72 & 0.24 & 2.68 & 1.09 & - & 4.53 & 4.64 & 6.73 & 13.21 & 16.01 & 17.78 \\
\hline $\mathrm{SrO}$ & - & - & - & - & - & 3.18 & 4.28 & - & - & - & - & 0.91 & - \\
\hline $\mathrm{BaO}$ & - & - & 0.12 & - & - & 26.08 & 14.53 & - & - & - & - & 0.33 & - \\
\hline $\mathrm{Na}_{2} \mathrm{O}$ & 8.58 & 9.45 & 8.63 & 8.83 & 6.28 & 0.94 & 2.97 & 7.72 & 7.32 & 6.51 & 3.83 & 2.01 & 0.55 \\
\hline $\mathrm{K}_{2} \mathrm{O}$ & 1.93 & 2.21 & 2.94 & 4.13 & 5.86 & 1.66 & 4.18 & 1.95 & 2.16 & 3.01 & 0.17 & 0.11 & 0.61 \\
\hline $\mathrm{P}_{2} \mathrm{O}_{5}$ & 0.06 & 0.45 & 0.50 & 0.28 & 0.81 & - & - & - & - & 0.43 & - & - & - \\
\hline $\mathrm{As}_{2} \mathrm{O}_{5}$ & - & 6.21 & - & 1.17 & 1.04 & - & - & - & - & 1.26 & - & - & 1.35 \\
\hline $\mathrm{SO}_{3}$ & - & 0.43 & - & - & - & - & - & 0.12 & - & 0.48 & - & - & - \\
\hline \multirow[t]{2}{*}{ Total } & 100.79 & 99.73 & 98.80 & 101.02 & 100.69 & 100.51 & 101.34 & 100.26 & 100.02 & 99.19 & 101.66 & 101.89 & 102.29 \\
\hline & Empiric & formul & e calcul & ed on the & basis of & ght $O$ ato & is per for & nula unit & & & & & \\
\hline $\mathrm{Si}$ & 2.81 & 2.55 & 2.82 & 2.86 & 2.70 & 2.17 & 2.53 & 2.79 & 2.73 & 2.74 & 2.30 & 2.12 & 2.02 \\
\hline $\mathrm{Ti}$ & 0.01 & 0.00 & 0.02 & 0.00 & - & - & - & 0.00 & - & 0.01 & - & - & 0.00 \\
\hline $\mathrm{Al}$ & 1.16 & 1.28 & 1.10 & 1.10 & 1.24 & 1.81 & 1.49 & 1.14 & 1.28 & 0.91 & 1.73 & 1.89 & 1.96 \\
\hline $\mathrm{Fe}^{3+}$ & 0.04 & 0.01 & 0.04 & 0.02 & 0.02 & 0.06 & - & 0.03 & 0.01 & 0.13 & 0.01 & 0.02 & 0.02 \\
\hline $\mathrm{Mg}$ & - & - & - & - & - & - & - & 0.04 & - & 0.08 & - & - & - \\
\hline $\mathrm{Ca}$ & 0.13 & 0.03 & 0.08 & 0.01 & 0.13 & 0.07 & - & 0.22 & 0.22 & 0.33 & 0.63 & 0.78 & 0.86 \\
\hline $\mathrm{Sr}$ & - & - & - & - & - & 0.10 & 0.13 & - & - & - & - & 0.02 & - \\
\hline $\mathrm{Ba}$ & - & - & 0.00 & - & - & 0.57 & 0.29 & - & - & - & - & 0.01 & - \\
\hline $\mathrm{Na}$ & 0.74 & 0.83 & 0.76 & 0.76 & 0.55 & 0.10 & 0.29 & 0.67 & 0.63 & 0.59 & 0.33 & 0.18 & 0.05 \\
\hline $\mathrm{K}$ & 0.11 & 0.13 & 0.17 & 0.23 & 0.34 & 0.12 & 0.27 & 0.11 & 0.12 & 0.18 & 0.01 & 0.01 & 0.04 \\
\hline $\mathrm{P}^{5+}$ & - & 0.02 & 0.02 & 0.01 & 0.03 & - & - & - & - & 0.02 & - & - & - \\
\hline $\mathrm{As}^{5+}$ & - & 0.15 & - & 0.03 & 0.02 & - & - & - & - & 0.03 & - & - & 0.03 \\
\hline$S^{6+}$ & - & 0.02 & - & - & - & - & - & 0.01 & - & 0.02 & - & - & - \\
\hline$\sum T+A$ & 5.00 & 5.02 & 5.02 & 5.02 & 5.03 & 5.00 & 5.00 & 5.00 & 5.00 & 5.03 & 5.01 & 5.02 & 4.98 \\
\hline
\end{tabular}

Note: Dash means "below detection limit". $\sum T+A=$ sum of all atoms except of oxygen. Analyses 7-12 correspond to the following varieties of plagioclases: nos. 7-9 - andesine, 10 - labradorite, 11 - bytownite, 12 - anorthite sensu stricto.

Kalsilite occurs in the polymineralic zone of the Arsenatnaya fumarole in association with different arsenates, hematite, As-bearing sanidine and members of the halitesylvite series. It forms well-shaped hexagonal prismatic crystals up to $20 \mu \mathrm{m}$ (Fig. 6) and porous white crusts on basalt scoria.

Kalsilite from the Arsenatnaya has the space group $P 6_{3}$ and unit-cell parameters $a=5.1562(5), c=8.6888(11) \AA$ and $V=200.06(4) \AA^{3}$ (Table S1 in the Supplement). Its crystal structure was solved on a single crystal and refined to final $R_{1}=4.47 \%$ on 389 reflections with $\mathrm{F}>2 \sigma \mathrm{F}$. The structure data on kalsilite are given in Tables S2 and S3.

The content of $\mathrm{As}_{2} \mathrm{O}_{5}$ in this kalsilite varies from $1.1 \mathrm{wt} \%$ to $6.6 \mathrm{wt} \%$ (Table 4 ). The mineral contains up to $1.0 \mathrm{wt} \% \mathrm{ZnO}$.

Leucite is a rare aluminosilicate in the Arsenatnaya fumarole. It typically occurs in holes of sanidine crystals (Fig. 6c). All studied leucite samples are enriched with arsenic: the mineral contains from $6.8 \mathrm{wt} \%$ to $10.5 \mathrm{wt} \% \mathrm{As}_{2} \mathrm{O}_{5}$ (Table 4).

The sodalite-group minerals sodalite and hauyne are common in the Arsenatnaya fumarole. They occur mainly in pores of basalt scoria and in fumarolic vents and are characterized by a diverse morphology of crystals and aggregates (Fig. 7). They form rhombic dodecahedral crystals up to $0.2 \mathrm{~mm}$ and their clusters, elongated pseudo-prismatic crystals (sometimes skeletal, case-like) typically combined in bush-like aggregates (Fig. 7), and spherulites. These feldspathoids usually overgrow hematite crystals or basalt scoria. They also form thin white crusts up to $2 \mathrm{~mm}$ across on basalt together with sanidine. Both feldspathoids are colourless or white, sometimes with a beige or green hue.

Sodalite and hauyne are associated with aphthitalite, anhydrite, metathénardite, sylvite, halite, aegirine, diverse arsenates, etc. In some samples these feldspathoids are covered by anhydrite and metathénardite whereas in other cases the 
Table 4. Chemical composition of leucite (Lc), kalsilite (Kls) and nepheline (Neph) from the Arsenatnaya fumarole.

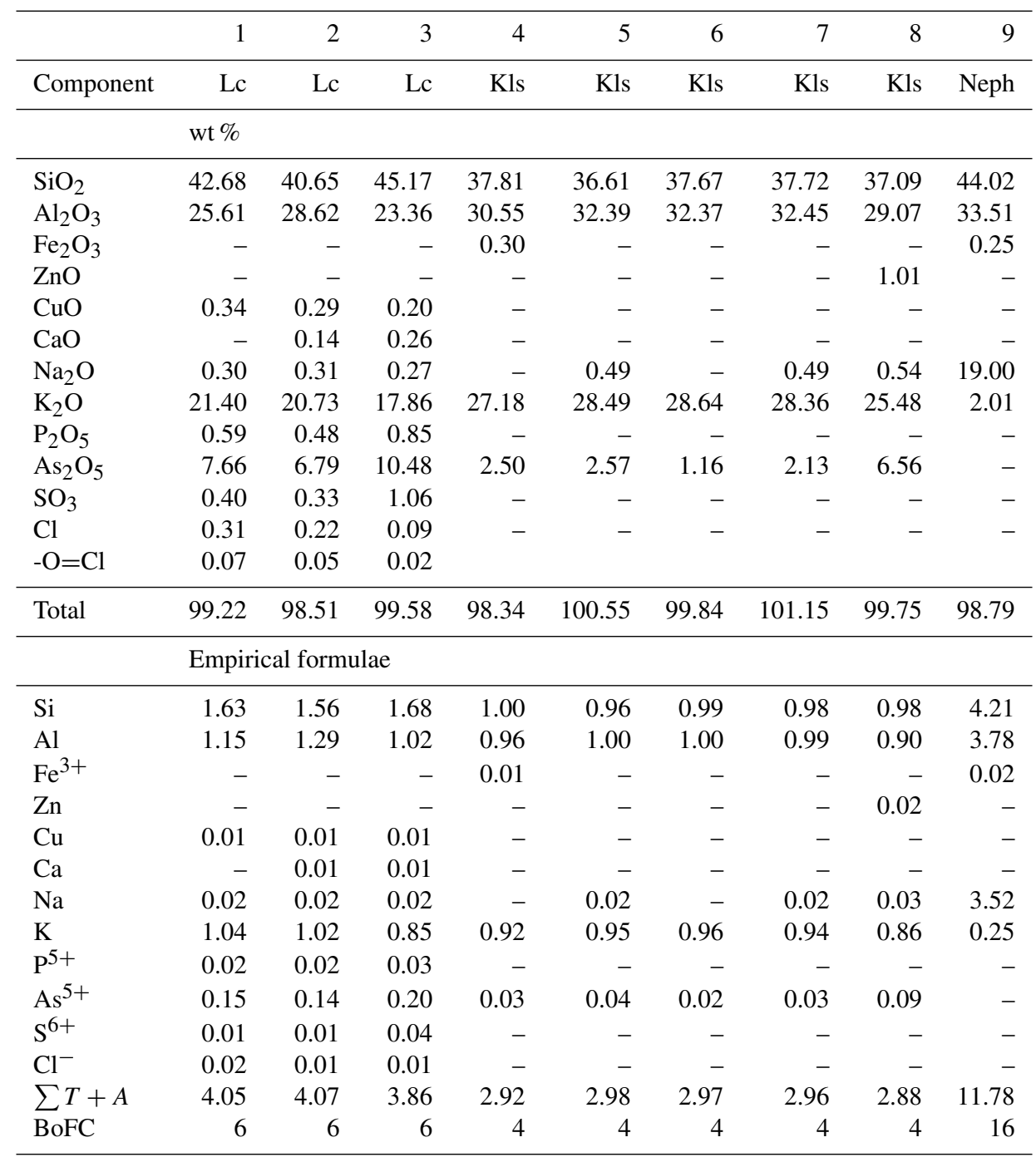

Note: Dash means "below detection limit". $\sum T+A=$ sum of all atoms except of oxygen. BoFC is a basis of formula calculation: number of $\mathrm{O}$ atoms per formula unit (apfu).

sodalite-group minerals overgrow arsenates (Fig. 7) together with anhydrite.

Representative chemical data on sodalite and hauyne from the Arsenatnaya fumarole are given in Table 5. Wide variations in components that occupy extra-framework (intracage) sites are typical for both minerals (Fig. 8). These variations lead to the formation of an isomorphous series between sodalite (Sod) and hauyne (Hau) within the limits $\mathrm{Hau}_{100}$ $\mathrm{Hau}_{44}$ (in the hauyne part of this series) and $\operatorname{Sod}_{100}-\operatorname{Sod}_{80}$ (in the sodalite part of the series).

Tolbachik sodalite and hauyne contain up to 1.8 and $2.5 \mathrm{wt} \% \mathrm{As}_{2} \mathrm{O}_{5}$, respectively.

The most intriguing feature of hauyne from the Arsenatnaya fumarole is the presence of earlier unknown varieties with significant molybdenum and/or tungsten admixtures: up to $4.2 \mathrm{wt} \% \mathrm{MoO}_{3}$ and up to $1.7 \mathrm{wt} \% \mathrm{WO}_{3}$.
Several samples of sodalite and hauyne from the Arsenatnaya fumarole were studied by single-crystal and powder XRD. The obtained data show that both sodalite and hauyne are cubic with space group $P \overline{4} 3 n$, which indicates an Al,Si-ordered tetrahedral framework. Powder XRD patterns of these samples are given in Table S4. The unit-cell parameters of sodalite are $a=8.870-8.881 \AA$ and $V=700.3$ $700.5 \AA^{3}$, and for hauyne they are $a=9.113-9.118 \AA$ and $V=756.6-758.1 \AA^{3}$.

\section{Tectosilicates from ancient fumarolic fields of Mountain 1004}

Among minerals from ancient, extinct fumarolic fields of Mountain 1004, we detected four tectosilicates: sanidine, anorthoclase, leucite and hauyne. All of them form thin white 
Table 5. Chemical composition of sodalite (Sod) and hauyne (Hau) from the Arsenatnaya fumarole.

\begin{tabular}{|c|c|c|c|c|c|c|c|c|c|c|c|c|c|}
\hline & 1 & 2 & 3 & 4 & 5 & 6 & 7 & 8 & 9 & 10 & 11 & 12 & $13^{*}$ \\
\hline \multirow[t]{2}{*}{ Component } & Sod & Sod & Hau & Hau & Hau & Hau & Hau & Hau & Hau & Hau & Hau & Hau & Hau \\
\hline & wt $\%$ & & & & & & & & & & & & \\
\hline $\mathrm{SiO}_{2}$ & 37.01 & 36.50 & 32.85 & 34.84 & 35.01 & 33.58 & 34.87 & 29.60 & 30.96 & 38.46 & 36.68 & 32.60 & 35.90 \\
\hline $\mathrm{Al}_{2} \mathrm{O}_{3}$ & 31.17 & 33.69 & 27.76 & 29.23 & 29.51 & 28.65 & 30.29 & 30.48 & 29.11 & 28.12 & 28.86 & 29.12 & 24.79 \\
\hline $\mathrm{Fe}_{2} \mathrm{O}_{3}$ & 0.72 & 0.37 & 0.70 & 0.39 & - & 0.33 & 0.23 & 0.16 & 0.15 & 0.71 & 0.60 & 0.89 & 0.63 \\
\hline $\mathrm{MgO}$ & - & - & - & 0.09 & - & - & - & - & - & 0.03 & 0.10 & 0.05 & - \\
\hline $\mathrm{CaO}$ & 0.54 & - & 8.04 & 5.85 & 3.43 & 5.25 & 4.43 & 12.10 & 11.50 & 7.80 & 8.43 & 10.28 & 9.04 \\
\hline $\mathrm{Na}_{2} \mathrm{O}$ & 23.53 & 24.16 & 15.90 & 17.30 & 15.40 & 15.46 & 19.15 & 11.66 & 12.94 & 9.47 & 10.09 & 9.72 & 12.89 \\
\hline $\mathrm{K}_{2} \mathrm{O}$ & 0.90 & 1.05 & 0.85 & 1.78 & 7.27 & 3.68 & 0.78 & 0.55 & 0.57 & 1.82 & 0.77 & 0.46 & 0.72 \\
\hline $\mathrm{As}_{2} \mathrm{O}_{5}$ & - & 1.22 & 1.93 & - & 1.77 & 0.63 & 0.82 & 0.73 & 0.77 & - & - & - & 0.49 \\
\hline $\mathrm{SO}_{3}$ & 2.02 & - & 13.43 & 10.86 & 6.16 & 10.57 & 8.97 & 11.22 & 12.46 & 11.99 & 11.12 & 11.86 & 10.63 \\
\hline $\mathrm{MoO}_{3}$ & - & - & - & - & - & - & - & 3.59 & 2.42 & 1.38 & 3.69 & 4.01 & 1.23 \\
\hline $\mathrm{WO}_{3}$ & - & - & - & - & - & - & - & - & - & 0.17 & - & 0.19 & 1.67 \\
\hline $\mathrm{Cl}$ & 6.22 & 7.28 & 0.12 & 1.46 & 3.46 & 0.82 & 2.01 & - & - & - & - & 0.16 & 0.11 \\
\hline$-\mathrm{O}=\mathrm{Cl}$ & 1.40 & 1.62 & 0.03 & 0.33 & 0.77 & 0.18 & 0.45 & - & - & - & - & 0.04 & 0.02 \\
\hline \multirow[t]{2}{*}{ Total } & 100.71 & 102.65 & 101.55 & 101.47 & 101.24 & 98.79 & 101.10 & 100.09 & 100.88 & 99.95 & 100.34 & 99.30 & 98.20 \\
\hline & \multicolumn{13}{|c|}{ Empirical formulae calculated on the basis of 12 framework-forming tetrahedrally coordinated atoms $[\mathrm{Si}+\mathrm{Al}+\mathrm{Fe}+\mathrm{As}]$} \\
\hline $\mathrm{Si}$ & 5.98 & 5.68 & 5.87 & 6.01 & 5.94 & 5.93 & 5.88 & 5.38 & 5.65 & 6.40 & 6.19 & 5.79 & 6.54 \\
\hline $\mathrm{Al}$ & 5.93 & 6.18 & 5.85 & 5.94 & 5.90 & 5.97 & 6.02 & 6.53 & 6.26 & 5.51 & 5.74 & 6.09 & 5.32 \\
\hline $\mathrm{Fe}^{3+}$ & 0.09 & 0.04 & 0.09 & 0.05 & - & 0.04 & 0.03 & 0.02 & 0.02 & 0.09 & 0.08 & 0.12 & 0.09 \\
\hline $\mathrm{Mg}$ & - & - & - & 0.02 & - & - & - & - & - & 0.01 & 0.03 & 0.01 & - \\
\hline $\mathrm{Ca}$ & 0.09 & - & 1.54 & 1.08 & 0.62 & 0.99 & 0.80 & 2.36 & 2.25 & 1.39 & 1.52 & 1.96 & 1.77 \\
\hline $\mathrm{Na}$ & 7.37 & 7.29 & 5.51 & 5.79 & 5.07 & 5.30 & 6.26 & 4.11 & 4.58 & 3.06 & 3.30 & 3.35 & 4.56 \\
\hline $\mathrm{K}$ & 0.19 & 0.21 & 0.19 & 0.39 & 1.57 & 0.83 & 0.17 & 0.13 & 0.13 & 0.39 & 0.17 & 0.10 & 0.17 \\
\hline $\mathrm{As}^{5+}$ & - & 0.10 & 0.18 & - & 0.16 & 0.06 & 0.07 & 0.07 & 0.07 & - & - & - & 0.05 \\
\hline$S^{6+}$ & 0.31 & - & 2.25 & 1.76 & 0.98 & 1.75 & 1.42 & 1.91 & 2.13 & 1.87 & 1.76 & 1.98 & 1.82 \\
\hline $\mathrm{Mo}^{6+}$ & - & - & - & - & - & - & - & 0.27 & 0.18 & 0.10 & 0.26 & 0.30 & 0.09 \\
\hline $\mathrm{W}^{6+}$ & - & - & - & - & - & - & - & - & - & 0.01 & - & 0.01 & 0.08 \\
\hline $\mathrm{Cl}^{-}$ & 1.70 & 1.92 & 0.04 & 0.43 & 0.99 & 0.25 & 0.57 & - & - & - & - & 0.05 & 0.03 \\
\hline
\end{tabular}

Note: Dash means “ below detection limit”. * Analysis 13 also contains 0.12 wt \% $\mathrm{TiO}_{2}$ that corresponds to 0.02 apfu Ti.

crusts consisting of tiny (up to $20 \mu \mathrm{m}$ ) white or colourless crystals on altered basalt. The main associated minerals are hematite, corundum, fluorite and spinel-group oxides (for a detailed description see Part 1).

The chemical composition of tectosilicates from paleofumaroles of Mountain 1004 is given in Table S5.

The powder XRD (Table 2) and Raman spectroscopic data (Fig. 3c) show that potassic feldspar from this locality is sanidine.

\section{Discussion}

\subsection{Species diversity and general features of fumarolic silicates}

Twenty-six valid mineral species and five insufficiently studied phases (their names are given in italics) belonging to silicates are found in Tolbachik fumaroles, namely forsterite, andradite, titanite, indialite, the $\mathrm{Cu}$ - and $\mathrm{Zn}$-rich analogue of roedderite, enstatite, clinoenstatite, diopside, aegirine, aegirine-augite, esseneite, "Cu,Mg-pyroxene", wollastonite, potassic-fluoro-magnesio-arfvedsonite, potassicfluoro-richterite, litidionite, fluorophlogopite, yangzhumingite, "fluoreastonite", the Sn analogue of dalyite, sanidine, anorthoclase, ferrisanidine, albite, anorthite, barium feldspar, leucite, nepheline, kalsilite, sodalite and hauyne. These silicates occur as well-shaped crystals and open-work aggregates in close association with other sublimate minerals in fumarolic vents or they replace basalt, forming rims in nearsurface blocks of basalt scoria and volcanic bombs which compose the walls of the vents. The brightest chemical feature of this mineralization is an enrichment (up to several percent of weight) of most silicates by chalcophile and other ore elements: As (the major admixture), $\mathrm{Cu}, \mathrm{Zn}, \mathrm{Sn}, \mathrm{Mo}$ and/or W. As shown by Meniaylov et al. (1980), fumarolic gases of the second scoria cone of the NB GTFE analysed during and after the eruption (in 1975-1976) contained As, $\mathrm{Cu}$ and $\mathrm{Zn}: 1.1,8-46$ and 5-22 $\mathrm{mg} \mathrm{m}^{-3}$, respectively. Thus, both morphological and chemical features undoubtedly indicate 

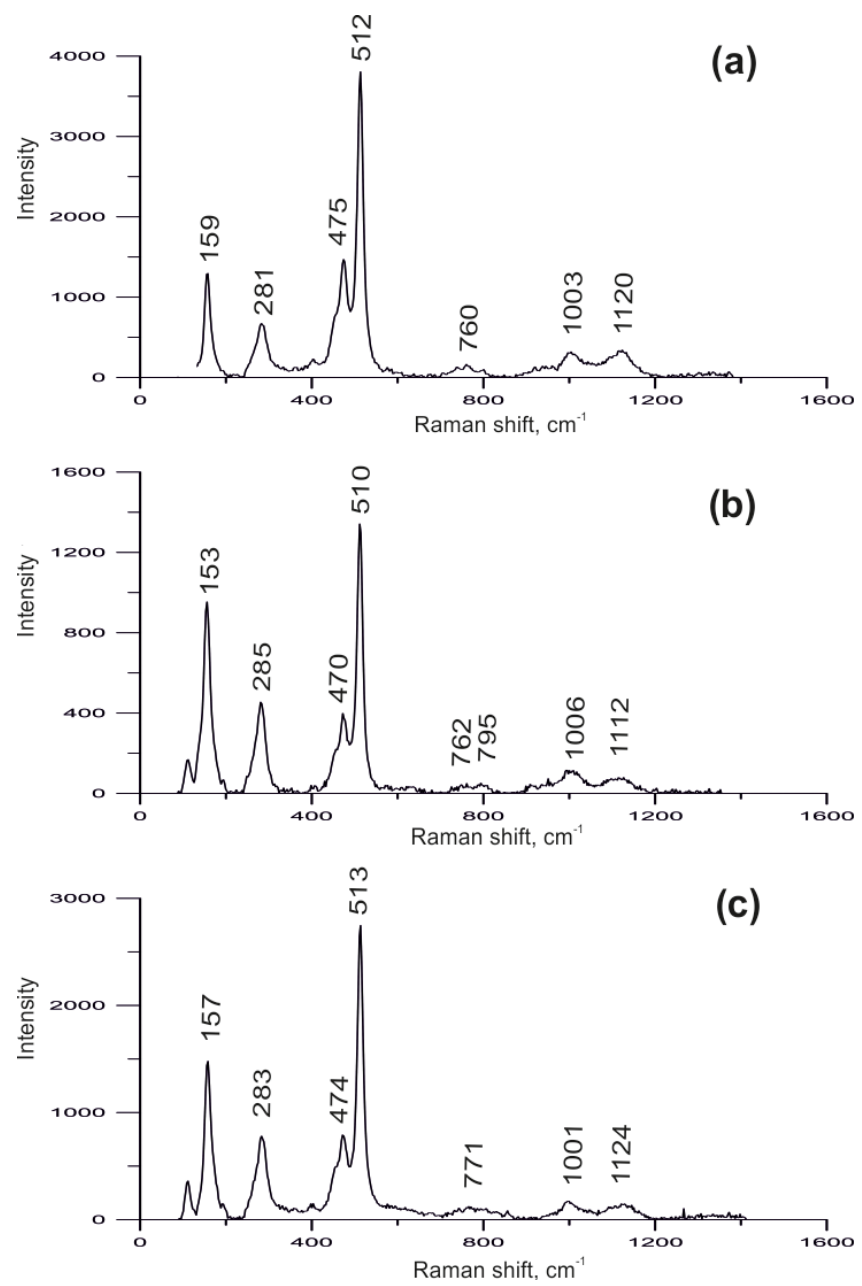

Figure 3. The Raman spectra of sanidine from the Arsenatnaya fumarole (a), the Yadovitaya fumarole (b) and the ancient fumarole of Mountain 1004 (c), all from the Tolbachik volcano.

these silicates to be the products of direct deposition from fumarolic gas or a result of interactions between this hot gas and host basalt.

Other general chemical features of silicates from Tolbachik fumaroles are (1) the presence of only trivalent iron and (2) the absence of hydrogen.

\subsection{Chemical and structural features of the main fumarolic silicates}

It seems interesting to discuss some data obtained for several silicates, emphasizing mainly the features that distinguish the minerals crystallized in a fumarole system from their counterparts formed in other geological formations.

The fumarolic arsenic- and phosphorus-rich variety of forsterite, containing up to $12.9 \mathrm{wt} \% \mathrm{P}_{2} \mathrm{O}_{5}$ and up to $16.0 \mathrm{wt} \% \mathrm{As}_{2} \mathrm{O}_{5}$, surpasses all known natural olivines in content. It concedes only the anthropogenic P-rich olivine (up to $23.1 \mathrm{wt} \% \mathrm{P}_{2} \mathrm{O}_{5}$ ) from the prehistoric sacrificial burn- ing site in Ötz Valley, Tyrol, Austria (Tropper et al., 2004; Schneider et al., 2013), and synthetic olivine samples (Boesenberg and Hewins, 2010). Our fumarolic forsterite is also the first among both natural and synthetic olivines in which the arsenic impurity was detected.

Enstatite and clinoenstatite occur in the Arsenatnaya fumarole in different temperature zones. Clinoenstatite was found only in the upper zone (Zone IV), whereas enstatite is spread in Zones VIa and VIb. This is in agreement with the data on stability fields of $\mathrm{Mg}_{2} \mathrm{Si}_{2} \mathrm{O}_{6}$ polymorphs: low clinoenstatite $\left(P 2_{1} / c\right)$ is stable below $600{ }^{\circ} \mathrm{C}$, whereas enstatite can exist in the temperature range $600-1000^{\circ} \mathrm{C}$ (Smyth, 1974).

All Fe-bearing silicates formed in the studied fumaroles contain only trivalent iron due to the highly oxidizing conditions of mineral formation (Pekov et al., 2018). In particular, the pyroxenes belong to the diopside-esseneite-aegirine solid-solution system instead of the most common diopsidehedenbergite-aegirine system for other endogenous geological formations.

The combination of high temperature, atmospheric pressure and the mechanism of crystallization involving hot gas which carries ore elements probably leads to formation of $\mathrm{H}$ free $\mathrm{Cu}$-enriched silicates including pyroxene with the idealized formula $\mathrm{CuMgSi}_{2} \mathrm{O}_{6}$, earlier known only as a synthetic compound (Tachi et al., 1997).

Fumarolic amphiboles (potassic-fluoro-magnesioarfvedsonite and potassic-fluoro-richterite) and mica (fluorophlogopite, fluoreastonite and yangzhumingite) are hydrogen-free. They contain $\mathrm{F}^{-}$and $\mathrm{O}^{2-}$ instead of $\mathrm{OH}^{-}$. Undoubtedly, this is a result of the crystallization under temperatures $>400^{\circ} \mathrm{C}$ and pressure close to atmospheric pressure. Thus, amphiboles and mica, the minerals considered to be the most important concentrators of hydrogen in the majority of high-temperature endogenous geological formations (especially in igneous and highly metamorphosed rocks), are completely $\mathrm{H}$-free in fumarolic deposits.

In previous works devoted to the mineralogy of Tolbachik fumaroles, any potassic feldspar, except for filatovite with As $>\mathrm{Si}$, was considered to be orthoclase (Serafimova, 1992; Vergasova et al., 2004; Vergasova and Filatov, 2016). In publications on minerals from fumaroles of the second scoria cone of the NB GTFE we also used the name orthoclase for potassic feldspar following this "tradition" (e.g. Pekov et al., 2014, 2018) because of the absence of both published and original exact data of the structural state of this mineral. Our previous studies of many samples of potassic feldspar from Tolbachik fumaroles using the Raman spectroscopy and powder XRD (including refinement of crystal structure using the Rietveld method) definitely show that this mineral is sanidine. Thus, now we are forced to refuse the term orthoclase sensu stricto in application to potassic feldspar from the studied Tolbachik fumaroles.

The sanidine-filatovite series is a single example of continuous solid-solution series between silicate and arsenate 

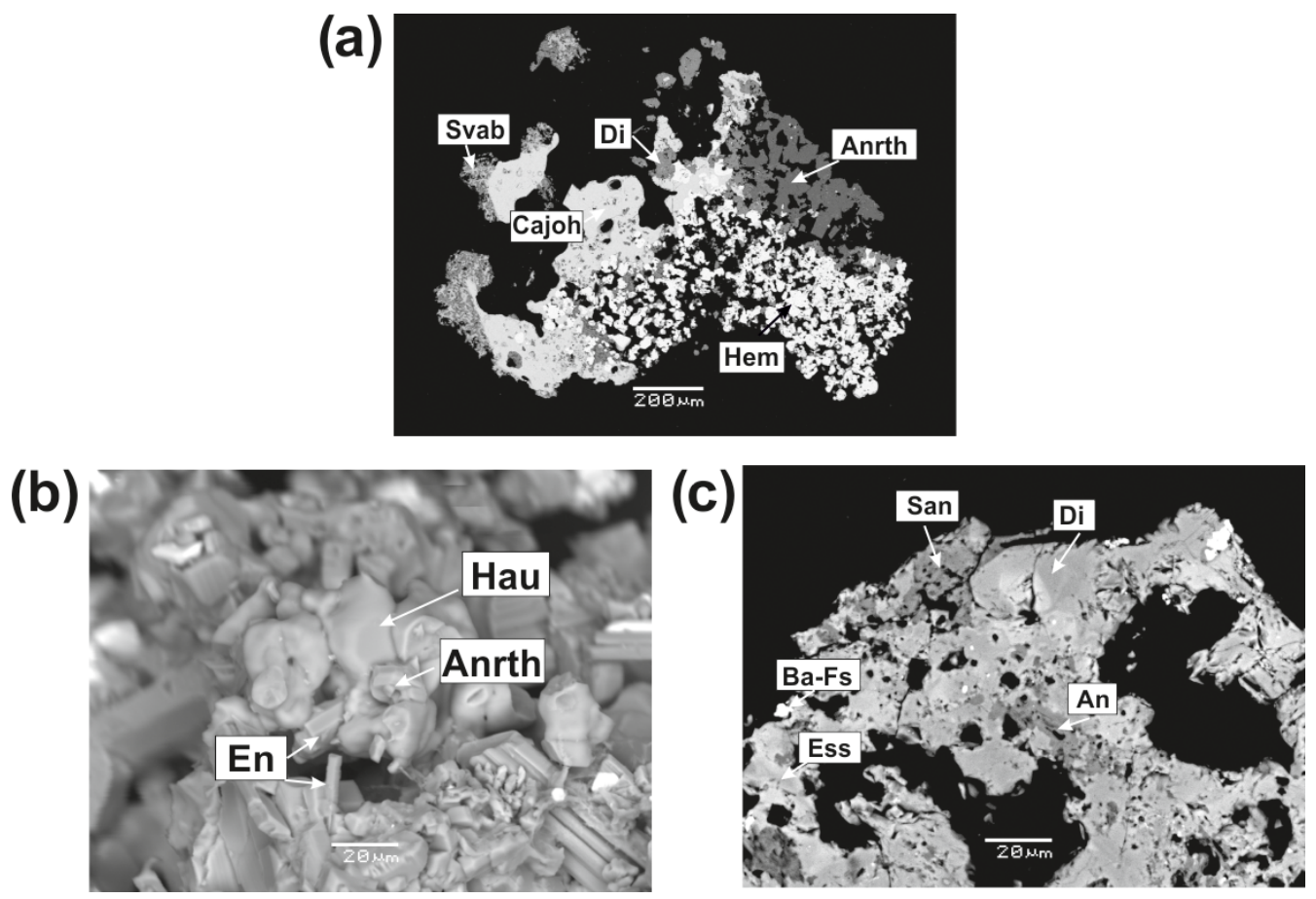

Figure 4. Anorthoclase (Anrth) and barium feldspar from the Arsenatnaya fumarole: aggregate of anorthoclase crystals with hematite (Hem), diopside (Di), svabite (Svab), calciojohillerite (Cajoh) (a); aggregate of hauyne crystals with anorthoclase and enstatite (En) (b); crust, consisting of diopside (Di) and sanidine (Snd) with inclusions of anorthite (An), esseneite (Ess) and barium feldspar (Ba Fs) (c). BSE images.

(a)

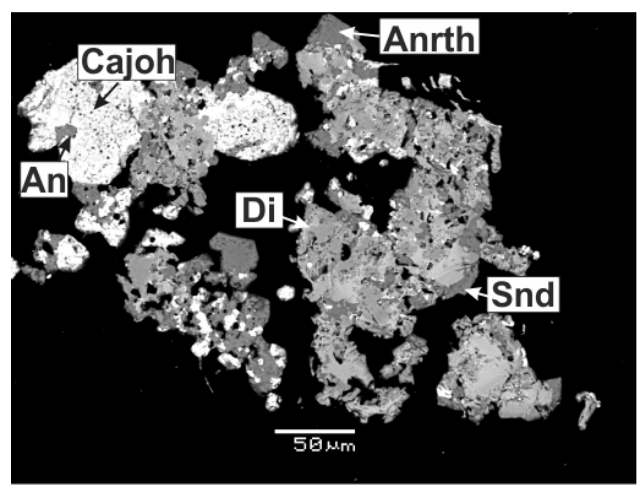

(b)

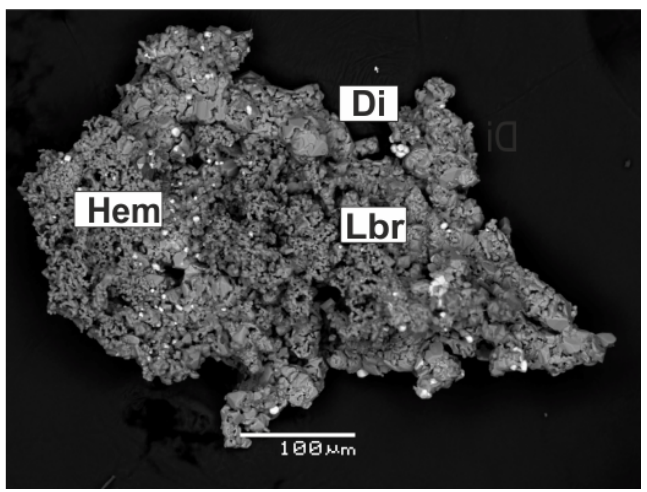

Figure 5. Plagioclases from the Arsenatnaya fumarole: inclusion of anorthite (An) in aggregate of calciojohillerite (Cajoh) associated with anorthoclase (Anrth), diopside (Di) and sanidine (Snd) (a); porous crust of labradorite (Lbr) with diopside and hematite (Hem) (b). BSE images.

found in nature. Zinc and copper are other specific impurities in sanidine from Tolbachik fumaroles that have never been reported for feldspars from other geological formations.

Several polymorphs are known for $\mathrm{KAlSiO}_{4}$ including three modifications of kalsilite sensu stricto, namely the lowtemperature trigonal form $\left(P \overline{3} 1 c\right.$, stable below $\left.500^{\circ} \mathrm{C}\right)$ and high-temperature hexagonal forms with space groups $P 6_{3} m c$ and $P 6_{3}$ (Perrotta et al., 1965; Kawahara et al., 1987; Cellai et al., 1997). Our data show that kalsilite from the Arsenatnaya fumarole crystallizes in space group $P 6_{3}$, which indicates a formation temperature $>500^{\circ} \mathrm{C}$.

The continuous solid-solution series between hauyne and sodalite was determined in sublimates of the Arsenatnaya fumarole: from $\mathrm{Hau}_{100}$ to $\mathrm{Hau}_{44}$. Such an extended solid solution has not been reported from nature and synthesis. In the synthesized solid-solution system, the phases with hauyne- 

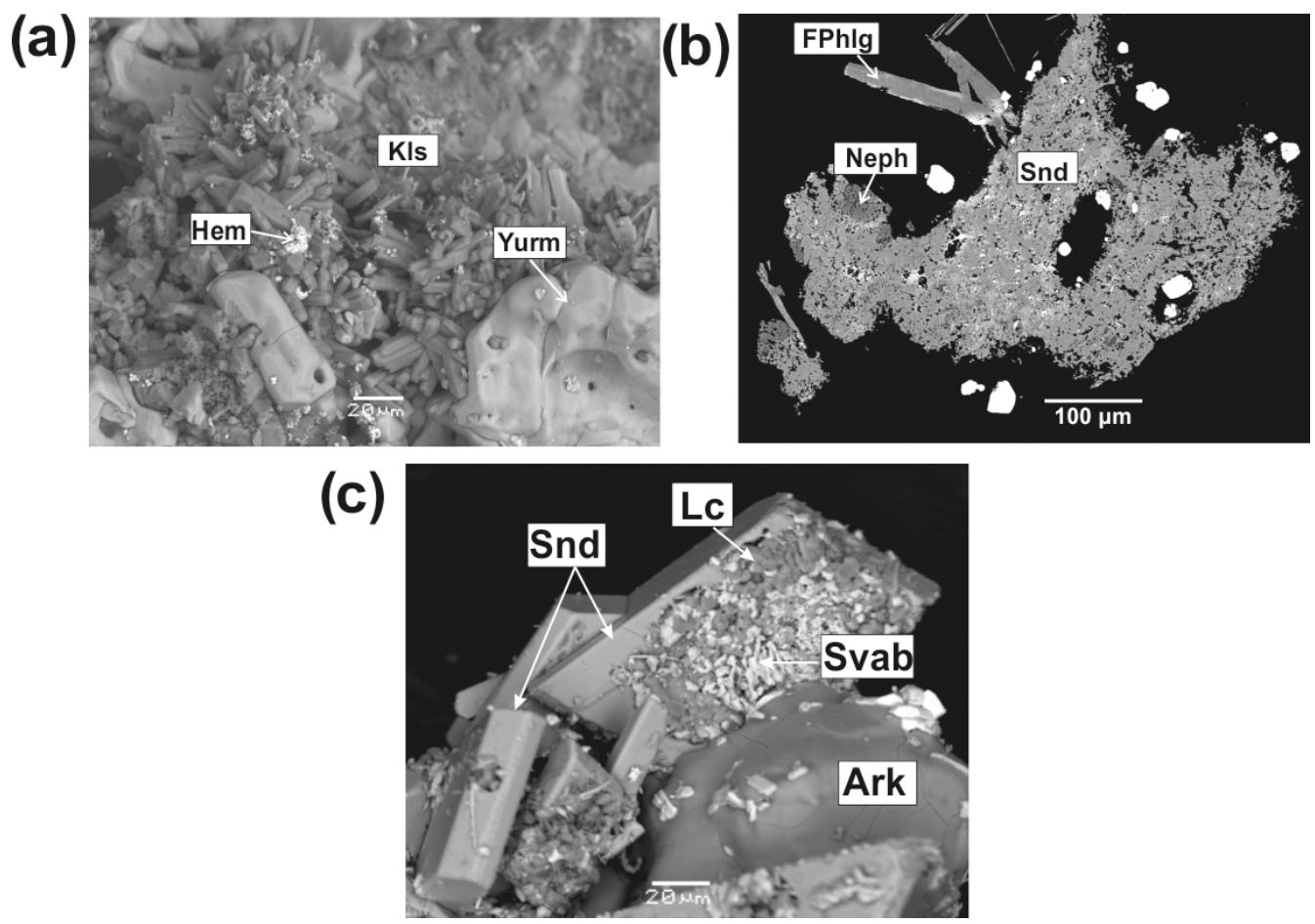

Figure 6. Kalsilite and nepheline from the Arsenatnaya fumarole: hexagonal prismatic crystals of kalsilite (Kls) with hematite (Hem) and yurmarinite (Yurm) (a); nepheline (Neph) in crust consisting of sanidine (Snd) with fluorophlogopite (FPhlg), leucite (Lc) with sanidine (Snd), hematite (Hem), svabite (Svab) and arkanite (Ark) (c). BSE images.
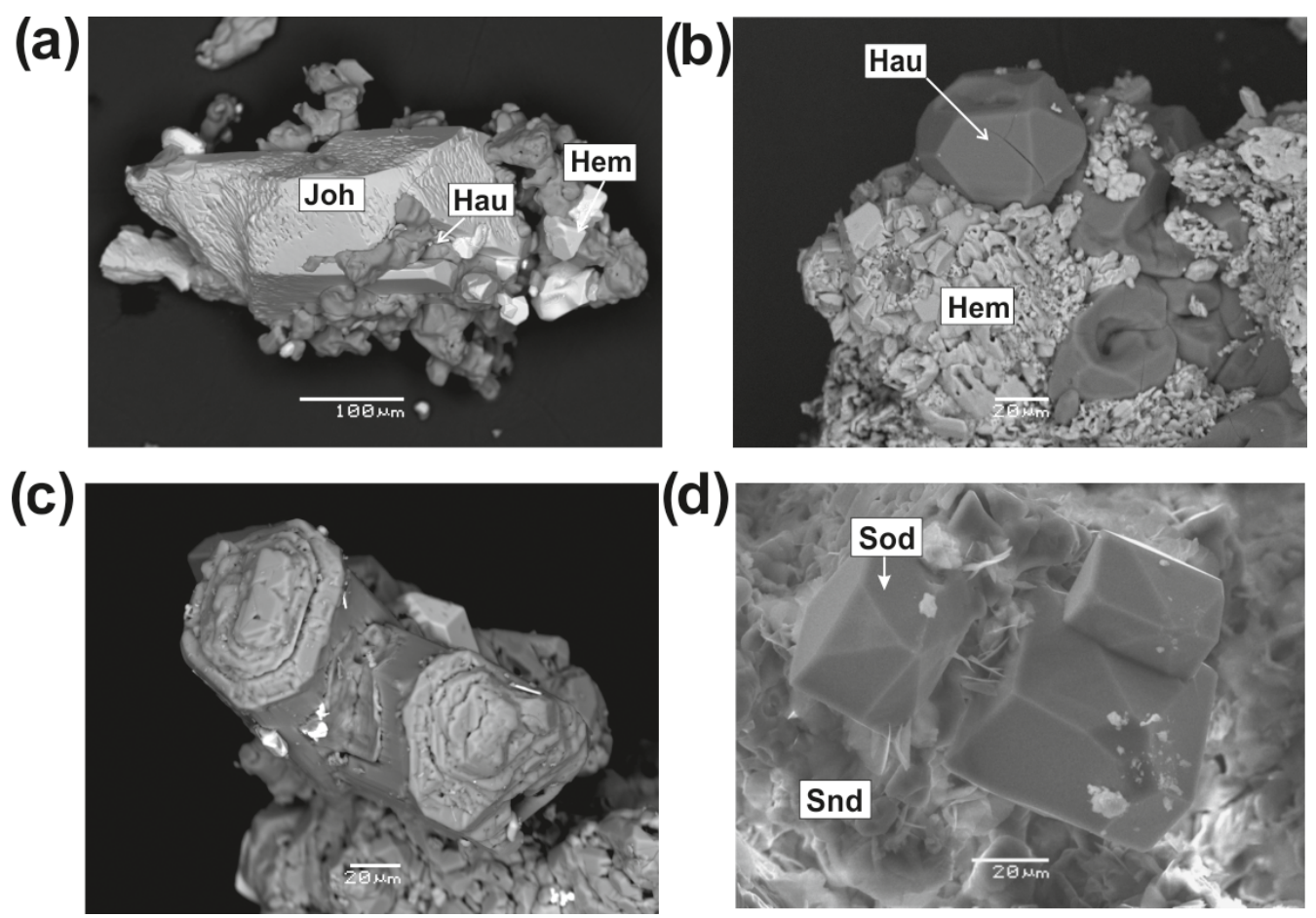

Figure 7. Hauyne (Hau) crystals and aggregates from the Arsenatnaya fumarole with hematite (Hem) and johillerite (Joh) (a-c); welldeveloped crystals of sodalite on sanidine aggregate (d). BSE images (a-c) and secondary electron (SE) image (d). 

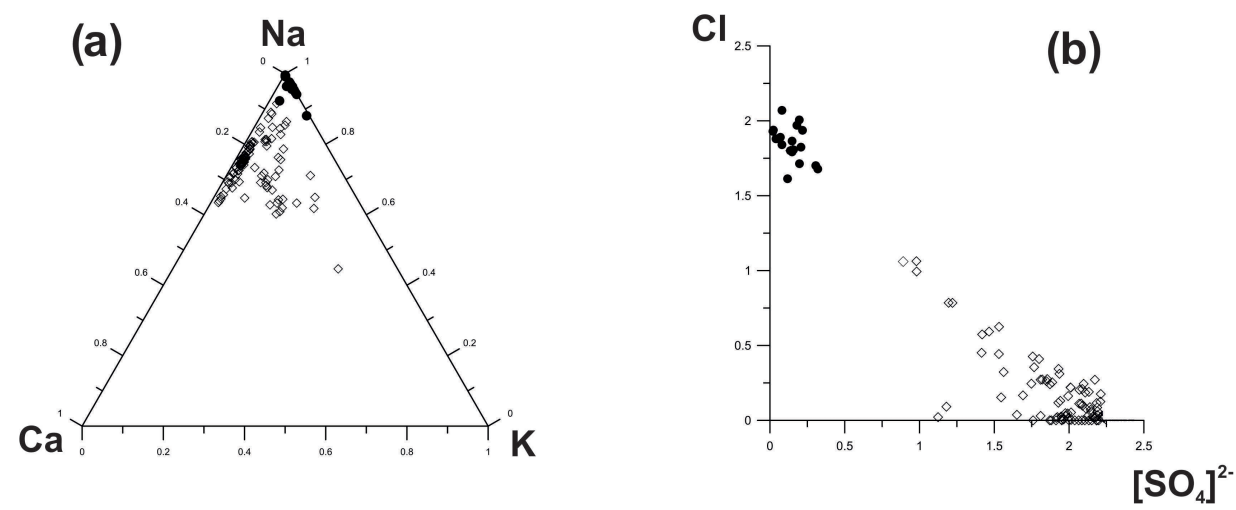

Figure 8. Ratios of major extra-framework cations and anions in sodalite (black circles) and hauyne (blank rhombs) from the Arsenatnaya fumarole.

nosean content below 75 mol \% demonstrated breakdown to hauyne and sodalite or to nosean and sodalite, depending on the chemistry of the studied system (Van Peteghem and Burley, 1963).

The intriguing crystal-chemical feature of hauyne from the Arsenatnaya fumarole is the presence of significant Mo and $\mathrm{W}$ impurities in some specimens. Such admixtures have not been reliably reported in minerals of the sodalite group. Zambonini (1910) mentioned sodalite with $2.5 \mathrm{wt} \% \mathrm{MoO}_{3}$ ("molybdosodalite") in a metamorphosed limestone xenolith embedded in lava of the famous Vesuvius volcano in Italy. However, no other data on this material were published. We believe that tetrahedral groups $\left(\mathrm{MoO}_{4}\right)^{2-}$ and $\left(\mathrm{WO}_{4}\right)^{2-}$ in the Tolbachik hauyne occur as additional anions substituting $\left(\mathrm{SO}_{4}\right)^{2-}$ in the intracage space, by analogy with the synthetic sodalite-type aluminates $\mathrm{Ca}_{8}\left[\mathrm{Al}_{12} \mathrm{O}_{24}\right]\left(\mathrm{MoO}_{4}\right)_{2}$ and $\mathrm{Ca}_{8}\left[\mathrm{Al}_{12} \mathrm{O}_{24}\right]\left(\mathrm{WO}_{4}\right)_{2}$ reported by Depmeier (1999).

The presence of high-temperature modifications of some silicates (enstatite, high sanidine, kalsilite and indialite) indirectly indicates that mineral assemblages in intermediate and especially deep zones of Tolbachik fumaroles were formed at temperatures of $500-800^{\circ} \mathrm{C}$. Such conclusion is in agreement with the data on temperature of fumarolic gas at the second scoria cone of the NB GTFE. The measurements performed in 1976 showed the temperature was about $700^{\circ} \mathrm{C}$ (Meniaylov et al., 1980).

The presence of feldspathoids, aegirine and alkali amphibole in deposits of the Arsenatnaya fumarole makes it possible to assume highly alkaline (agpaitic?) conditions of formation for these sublimates.

\subsection{Isomorphism in fumarolic silicates}

The majority of silicates found in Tolbachik fumaroles belong to widespread mineral species. They are representatives of groups containing the most common rock-forming minerals olivine, garnet, pyroxenes, amphiboles, mica, feldspars and feldspathoids. However, unlike their counterparts from other geological formations, nearly all these minerals contain significant impurities of chalcophile and/or other ore components, as well as $\mathrm{Ti}$ and $\mathrm{P}$. Isomorphic substitutions with participation of ore elements in silicates from fumaroles of the Tolbachik volcano involve all types of structural sites, except for $\mathrm{O}$ atoms coordinating $\mathrm{Si}$. Below we list important substitution schemes for different fumarolic silicates (Roman numerals mean coordination numbers).

The impurities of $\mathrm{As}^{5+}$ and $\mathrm{P}^{5+}$ in silicates substitute $\mathrm{Si}$. The substitution schemes are as follows:

${ }^{\mathrm{VI}} \mathrm{Mg}^{2+}+2^{\mathrm{IV}} \mathrm{Si}^{4+} \leftrightarrow{ }^{\mathrm{VI}}[\mathrm{vac}]^{0}+2^{\mathrm{IV}} T^{5+}$ in which

$T^{5+}=\mathrm{P}$, As and [vac] is vacancy (for forsterite);

$\mathrm{Ti}^{4+}+\mathrm{Si}^{4+} \leftrightarrow M^{3+}+\mathrm{As}^{5+}$ in which

$M=\mathrm{Fe}, \mathrm{V}, \mathrm{Cr}, \mathrm{Al}$ (for titanite);

$\mathrm{Ca}^{2+}+\mathrm{Si}^{4+} \leftrightarrow \mathrm{Na}^{+}+\mathrm{As}^{5+}$ (for pyroxenes and amphiboles); $2^{\mathrm{IV}} \mathrm{Si}^{4+} \leftrightarrow{ }^{\mathrm{IV}} M^{3+}+{ }^{\mathrm{IV}} \mathrm{As}^{5+}$ in which $M^{3+}=$

$\mathrm{Fe}, \mathrm{Al}$ (for titanite, andradite, pyroxenes, amphiboles, and phyllo- and tectosilicates).

Incorporation of $\mathrm{As}^{5+}$ at tetrahedral sites in tectosilicates can also be accompanied by additional substitution in the framework

${ }^{\mathrm{IV}} \mathrm{Al}^{3+}+{ }^{\mathrm{IV}} \mathrm{Si}^{4+} \leftrightarrow{ }^{\mathrm{IV}} M^{2+}+{ }^{\mathrm{IV}} \mathrm{As}^{5+}$ in which $M^{2+}$

$=\mathrm{Mg}, \mathrm{Zn}, \mathrm{Cu}$.

The substitutions involving $\mathrm{Sn}^{4+}$ in neso-, cyclo-, ino- and phyllosilicates are

$$
\begin{aligned}
& \mathrm{Ca}^{2+}+{ }^{\mathrm{VI}} M^{3+} \leftrightarrow M^{+}+{ }^{\mathrm{VI}} M^{4+} \text { in which } M^{+}=\mathrm{Na}, \mathrm{K}, \\
& M^{3+}=\mathrm{Fe}, \mathrm{Al} \text { and } M^{4+}=\mathrm{Ti}, \mathrm{Sn} ; \\
& { }^{\mathrm{VI}} M^{3+}+{ }^{\mathrm{IV}} \mathrm{Si}^{4+} \leftrightarrow{ }^{\mathrm{VI}} M^{4+}+{ }^{\mathrm{IV}} \mathrm{Al}^{3+} \text { in which } M^{4+} \\
& =\mathrm{Ti}, \mathrm{Sn} .
\end{aligned}
$$


The assumed substitution involving $\mathrm{Mo}^{6+}$ and $\mathrm{W}^{6+}$ in hauyne is

$$
\left(M^{6+} \mathrm{O}_{4}\right)^{2-} \leftrightarrow\left(\mathrm{SO}_{4}\right)^{2-} \text { in which } M^{6+}=\mathrm{Mo}, \mathrm{W} .
$$

The heterovalent substitutions of $\mathrm{F}^{-}$for $\mathrm{O}^{2-}$ in an additional anion of titanite, amphiboles and mica can be described by the following substitutional schemes:

$\mathrm{O}^{2-}+{ }^{\mathrm{VI}} M^{4+} \leftrightarrow \mathrm{F}^{-}+{ }^{\mathrm{VI}} M^{3+}$ in which $M^{3+}=$

$\mathrm{Al}, \mathrm{Fe}$ and $M^{4+}=\mathrm{Ti}, \mathrm{Sn}$;

$\mathrm{O}^{2-}+{ }^{\mathrm{IV}} \mathrm{Si}^{4+} \leftrightarrow \mathrm{F}^{-}+{ }^{\mathrm{IV}} M^{3+}$ in which $M^{3+}=\mathrm{Al}, \mathrm{Fe}$.

For mica of the yangzhumingite-fluorophlogopite series we suggest two main substitution schemes:

$\mathrm{Mg}^{2+}+2 \mathrm{Al}^{3+} \leftrightarrow[\mathrm{vac}]^{\mathrm{o}}+2 \mathrm{Si}^{4+}$ in which [vac] is

a vacancy in the sites of octahedrally coordinated cations;

$\mathrm{K}^{+}+\mathrm{Al}^{3+} \leftrightarrow[\mathrm{vac}]^{\mathrm{o}}+\mathrm{Si}^{4+}$ in which [vac] is

a vacancy in the interlayer cation site.

\subsection{Zonation in distribution of fumarolic silicates and its genetic principles}

The distribution of lithophile metals in the studied fumarole system reflects a zonation clearly observed in vertical section, from deep to upper parts, of the Arsenatnaya fumarole (Fig. 9).

Magnesium and $\mathrm{Ca}$ are the main cations in minerals from Zones VIa and VIb. They are species-defining components in the most common silicates of these zones, diopside (Zone VI), forsterite and enstatite (Zone VIb), as well as in the major non-silicate minerals - anhydrite (the most widespread mineral in Zone VI), fluorapatite-svabite series members, calciojohillerite and berzeliite. In contrast, in Zones V and IV, calcium minerals are not essential, whereas Mg-enriched mineralization is traced up to Zone IV. The main silicate of the upper part of Zone VIa and of Zones $\mathrm{Vb}$ and $\mathrm{Va}$ is fluorophlogopite, which forms practically monomineralic crusts and pods.

The alkali metals $\mathrm{Na}$ and $\mathrm{K}$ differ in behaviour from one another. In Zones VIa and VIb, minerals with speciesdefining sodium are not essential whereas potassium-bearing minerals are practically absent there. Sodium is fixed in pyroxenes (they are the main $\mathrm{Na}$ minerals in Zones VIa and VIb, including aegirine), plagioclases and anorthoclase, as well as in arsenates, namely calciojohillerite and berzeliite. Potassium occurs only as an insignificant impurity in hauyne, sodic feldspar and some arsenates. Its content strongly increases toward upper zones. Potassium becomes the speciesdefining component in the crust-forming minerals fluorophlogopite (Zones $\mathrm{Va}$ and $\mathrm{Vb}$ ), sanidine (Zones Va and IV), aphthitalite- and langbeinite-type sulfates, and sylvite. These zones also contain sodium feldspathoids. The major nonsilicate $\mathrm{Na}$ minerals are halite and aphthitalite-family sulfates.

The behaviour of $\mathrm{Al}$ resembles that of $\mathrm{K}$. The amount of $\mathrm{Al}$ gradually increases from Zone VIb via VIa to $\mathrm{V}$ and, especially, IV. In Zones $\mathrm{Va}$ and $\mathrm{Vb}, \mathrm{Al}$ is incorporated mainly in fluorophlogopite whereas in Zone IV sanidine (including the As- and Al-enriched varieties) becomes the major phase of Al. K-bearing feldspathoids are also common. It is interesting to note that (1) silicates are the major concentrators of alumina in deposits of these fumaroles (the role of sulfates, oxides, fluorides and minerals of other chemical classes is minor) and (2) tetrahedral coordination of $\mathrm{Al}$ is strongly predominant in fumarolic silicates: there are tectoaluminosilicates, fluorophlogopite with significant prevailing of $\mathrm{Mg}$ in octahedral sites and pyroxenes with Al mainly substituting Si.

Trivalent $\mathrm{Fe}$ is an important component in sublimates from all zones of the studied fumaroles. Its main carrier is hematite (in some zones, together with $\mathrm{Fe}^{3+}$-rich arsenates; Pekov et al., 2018). Silicates with species-defining $\mathrm{Fe}^{3+}$ (esseneite, aegirine and andradite) are not so common, nor are silicates with significant $\mathrm{Fe}^{3+}$ admixture.

The zonation of silicate mineralization in the vertical section of the Arsenatnaya fumarole, from deep to upper parts (except for minor minerals), is diopside + forsterite + enstatite + andradite $\rightarrow$ diopside $\rightarrow$ fluorophlogopite + diopside $\rightarrow$ sanidine + fluorophlogopite $\rightarrow$ sanidine (Fig. 9). We believe that it corresponds to the sequence of zones formed with temperature decrease.

This order of mineral assemblages along the upwards section of the Arsenatnaya fumarole roughly resembles the well-known Bowen's fractional crystallization series. The comparison of the scheme of segregation of major femic and salic rock-forming minerals from melt suggested by Bowen (1922) for calc-alkaline rocks and our scheme of zonation of fumarolic silicate mineralization is displayed in Fig. 10. As known, the order of mineral assemblages in the Bowen's series is caused mainly by the different liquidus temperatures for $\mathrm{Mg}, \mathrm{Ca}$ and $\mathrm{Fe}$ silicates and $\mathrm{K}$ and $\mathrm{Na}$ aluminosilicates. The end of the fractional crystallization of igneous rock is the system including quartz, potassic feldspar, albite, nepheline, leucite and kalsilite (Bowen, 1937; Thornton and Tuttle, 1960).

In the Arsenatnaya fumarole we observe the vertical zonation with the sequence of silicates, resembling the Bowen's series, within only $1.5 \mathrm{~m}$ (Figs. 9 and 10). At the upper part of the fumarole, we observe the same alkali silicate mineralization (sanidine, hauyne, sodalite, kalsilite, leucite), which is inherent for Bowen's residual liquid.

Nevertheless, despite the Bowen's fractional crystallization series which is applied to igneous rocks in our case, such distribution of the above-discussed components (and relevant minerals indeed) along the vertical section of the Arsenat- 


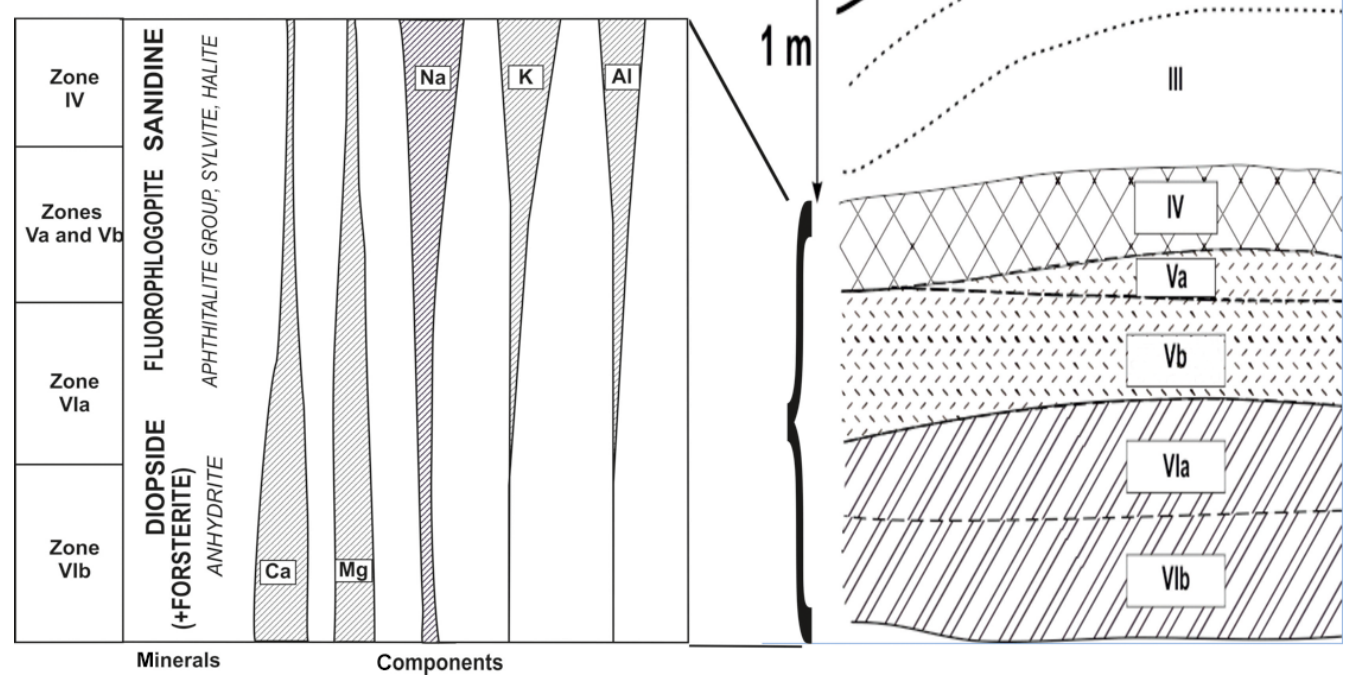

Figure 9. Distribution of the main mineral-forming lithophile metals in the zones of the Arsenatnaya fumarole containing silicate mineralization.

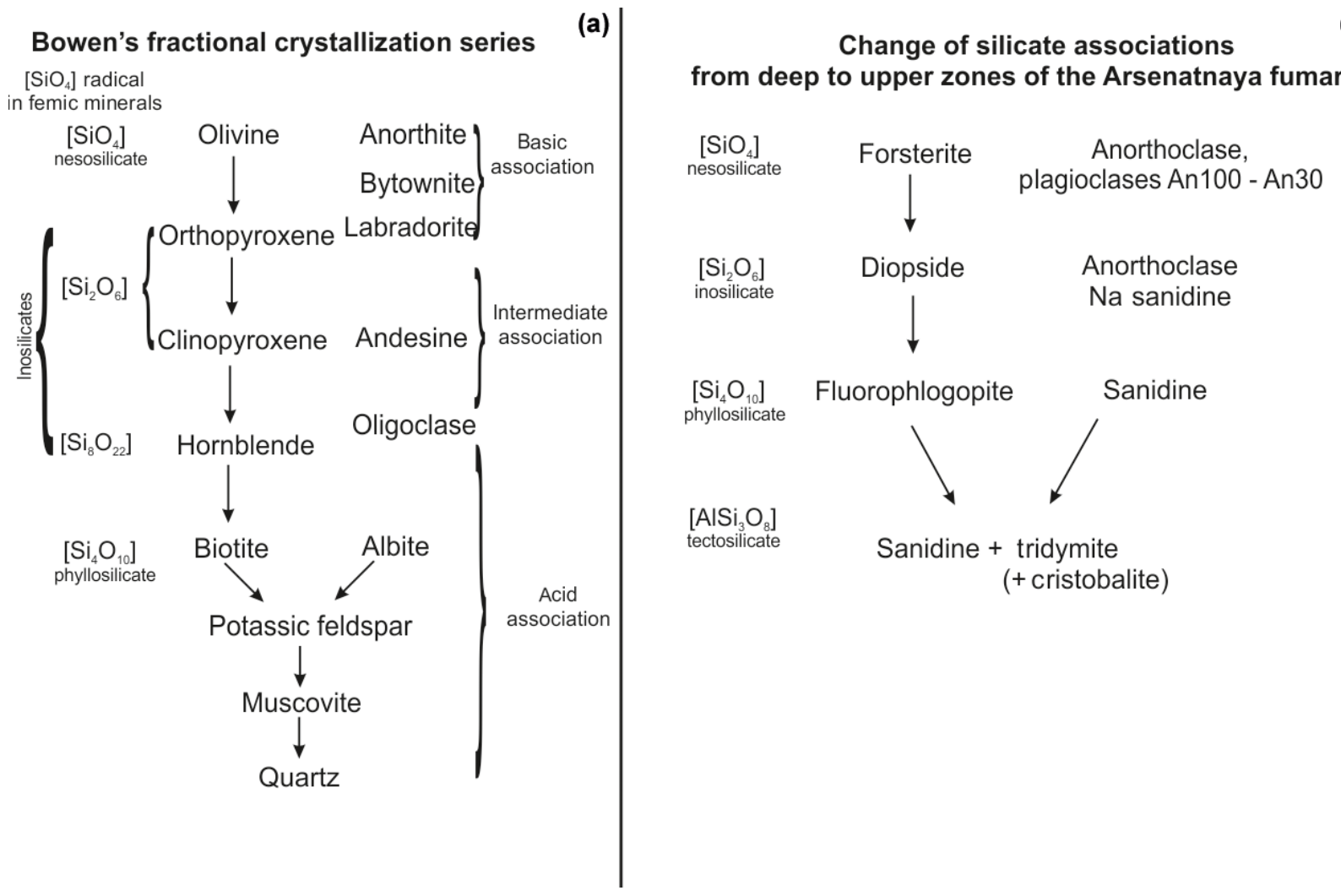

Figure 10. Comparison of Bowen's crystallization series (a; composed using the diagram by Bowen, 1922) and the distribution of silicate minerals along the vertical section (arrows mark the evolution of mineral composition from deep to upper zones) of the Arsenatnaya fumarole (b). 
naya fumarole likely reflects their relative volatilities in fumarole gas in the temperature range $500-1000^{\circ} \mathrm{C}$. For instance, the calculated volatilities of these elements in gas of the Mount St. Helens volcano (Washington, USA) at $930^{\circ} \mathrm{C}$ and $1 \mathrm{~atm}$ are as follows (concentrations are given in mole percent): $1.3 \times 10^{-10}$ for $\mathrm{Ca}, 2.2 \times 10^{-9}$ for $\mathrm{Mg}, 2.9 \times 10^{-8}$ for $\mathrm{Al}, 7.1 \times 10^{-5}$ for $\mathrm{K}$ and $2.0 \times 10^{-4}$ for $\mathrm{Na}$ (Symonds and Reed, 1993). The gases and aerosols emanating from a lava-tube window during the 2012-2013 eruption of the Ploskiy Tolbachik volcano show the following average concentrations of $\mathrm{Ca}, \mathrm{Mg}, \mathrm{Al}, \mathrm{Na}$ and $\mathrm{K}$ in gas (ppm): 4.5, 0.9, 7.9, 224 and 150, respectively (Zelenski et al., 2014). The logarithms of enrichment factors that reflect the partition of these elements between gas and solid phases are as follows: 0.38 for $\mathrm{Ca}, 0.0$ for $\mathrm{Mg}, 0.42$ for $\mathrm{Al}, 2.37$ for $\mathrm{Na}$ and 2.55 for $\mathrm{K}$. However, the significant influence of vertical temperature gradient cannot be excluded because the studied mineralization was formed in a near-surface, open fumarolic system.

In general, these data could explain the distribution of major species-defining lithophile metals in sublimates of Arsenatnaya and other Tolbachik fumaroles from deep to upper zones (Fig. 9). The less volatile $\mathrm{Ca}$ and $\mathrm{Mg}$ are mainly fixed in minerals in deep zones while more volatile $\mathrm{K}$ and $\mathrm{Na}$ "fly" to upper zones. Aluminium, being less volatile than $\mathrm{K}$ and $\mathrm{Na}$, may be extracted (mobilized) from the wall rocks under the influence of hot gas enriched by alkaline components. This can cause the appearance of mineral assemblages, including ones replacing a basalt scoria, which consist mainly of aluminosilicates: sanidine, kalsilite, leucite, sodalite and hauyne. The mechanism of Si mobilization seems to be an erosion of wall rock (basalt) by gas. However, it is not excluded that part of Si could be carried by volcanic gas.

From a crystal-chemical viewpoint, the main regularity along the vertical section of the Arsenatnaya fumarole is an increasing degree of condensation of a $\mathrm{Si}, \mathrm{O}$ tetrahedral motif. This resulted in change of major topological types of silicates: nesosilicates (forsterite) $\rightarrow$ inosilicates (diopside) $\rightarrow$ phyllosilicates (fluorophlogopite) $\rightarrow$ tectosilicates (sanidine). Such change of topological types of silicate structures is also inherent to the Bowen's fractional crystallization series (Fig. 10). Probably, the mechanism of crystallization (from melt or gas phase) in the temperature gradient does not influence the change of the topology of the $\mathrm{Si}, \mathrm{O}$ motif. This sequence reflects the changes in the system of chemical bonds in the series nesosilicates $\rightarrow$ inosilicates $\rightarrow$ phyllosilicates $\rightarrow$ tectosilicates (Ramberg, 1952). Together with relative volatilities of the species-defining components and their chemical characteristics (charge, radius and electronegativity), this factor can cause the observed zonation.

Data availability. All data used are given in the tables, figures and text and in the Supplement to this paper.
Supplement. The supplement related to this article is available online at: https://doi.org/10.5194/ejm-32-121-2020-supplement.

Author contributions. NVS and IVP wrote the paper. NVS and NVZ carried out the crystal structure analysis. NVS obtained Raman spectroscopic data. NVS and SNB obtained and processed $\mathrm{X}$-ray diffraction data. NNK and DAV processed electron microprobes. IVP and EGS collected and prepared samples.

Competing interests. The authors declare that they have no conflict of interest.

Acknowledgements. We thank the two anonymous referees for their valuable comments and Sergey V. Krivovichev and Christian Chopin for the editor work. This work was supported by the Russian Science Foundation, grant no. 19-17-00050 (as a part of mineralogical studies), and the Russian Foundation for Basic Research, grant 18-05-00332 (as a part of XRD and structural studies of feldspathoids). The technical support by the SPbSU X-Ray Diffraction Resource Center is acknowledged.

Financial support. This research has been supported by the Russian Science Foundation (grant no. 19-17-00050) and the Russian Foundation for Basic Research (grant 18-05-00332).

Review statement. This paper was edited by Sergey Krivovichev.

\section{References}

Boesenberg, J. S. and Hewins, R. H.: An experimental investigation into the metastable formation of phosphoran olivine and pyroxene, Geochim. Cosmochim. Ac., 74, 1923-1941, 2010.

Bowen, N. L.: The reaction principle in petrogenesis, J. Geol., 30, 177-198, 1922.

Bowen, N. L.: Recent high-temperature research on silicates and its significance in igneous geology, Am. J. Sci., 33, 1-21, 1937.

Cellai, D., Bonazzi, P., and Carpenter, M. A.: Natural kalsilite, $\mathrm{KAlSiO}_{4}$, with $P 31 c$ symmetry: crystal structure and twinning, Am. Mineral., 82, 276-279, 1997.

Deer, W. A., Howie, R. A., and Zussman, J.: Rock-forming Minerals, Framework Silicates: Feldspars, 2nd Edn., London, Geological Society, 2001.

Depmeier, W.: Structural distortions and modulations in microporous materials, Molec. Siev., 2, 113-137, 1999.

Ferguson, R. B., Ball, N. A., and Cerny, P.: Structure refinement of an adularian end-member high sanidine from the Buck Claim pegmatite, Bernic Lake, Manitoba, Can. Mineral., 29, 543-552, 1991.

Finney, J. J. and Bailey, S. W.: Crystal structure of an authigenic maximum microcline, Z. Kristallogr., 119, 413-436, 1977.

Freeman, J. J., Wang, A., Kuebler, K. E., Jolliff, B. L., and Haskin, L. A.: Characterization of natural feldspars by Raman spec- 
troscopy for future planetary exploration, Can. Mineral., 46, 1477-1500, 2008.

Kawahara, A., Andou, Y., Marumo, F., and Okuno, M.: The crystal structure of the high temperature form of kalsilite $\mathrm{KAlSiO}_{4}$ at 950 ${ }^{\circ}$ C, Mineral. J., 13, 260-270, 1987.

Kroll, H. and Ribbe, P. H.: Determining (Al,Si) distribution and strain in alkali feldspars using lattice parameters and diffractionpeak positions: a review, Am. Mineral., 72, 491-506, 1987.

Meniaylov, I. A., Nikitina, L. P. and Shapar, V. N.: Geochemical Features of Exhalations of the Great Tolbachik Fissure Eruption, Nauka Publishing, Moscow, 1980.

Pekov, I. V., Zubkova, N. V., Yapaskurt, V. O., Belakovskiy, D. I., Lykova, I. S., Vigasina, M. F., Sidorov, E. G., and Pushcharovsky, D. Yu.: New arsenate minerals from the Arsenatnaya fumarole, Tolbachik volcano, Kamchatka, Russia, I. Yurmarinite, Na7 $\left(\mathrm{Fe}^{3+}, \mathrm{Mg}, \mathrm{Cu}\right)_{4}\left(\mathrm{AsO}_{4}\right)_{6}$, Mineral. Mag., 78, 905-917, 2014.

Pekov, I. V., Koshlyakova, N. N., Zubkova, N. V., Lykova, I. S., Britvin, S. N., Yapaskurt, V. O., Agakhanov, A. A., Shchipalkina, N. V., Turchkova, A. G., and Sidorov, E. G.: Fumarolic arsenates - a special type of arsenic mineralization, Eur. J. Mineral., 30, 305-322, 2018.

Perrotta, A. J., Smith, S. M., and Smith, J. V.: The crystal structure of kalsilite, $\mathrm{KAlSiO}_{4}$, Mineral. Mag., 35, 588-617, 1965.

Ramberg, H.: Chemical bonds and distribution of cations in silicates, J. Geol., 60, 331-355, 1952.

Schneider, P., Tropper, P., and Kaindl, R.: The formation of phosphoran olivine and stanfieldite from the pyrometamorphic breakdown of apatite in slags from a prehistoric ritual immolation site (Goldbichl, Igls, Tyrol, Austria), Mineral Petrol., 107, 327-340, 2013.

Serafimova, E. K.: Mineral paragenesis of volcanic exhalations, Post-eruptive mineral formation on active volcanoes of Kamchatka, P. I. Far Eastern Branch of RAS, 31-52, 1992.

Shchipalkina, N. V., Pekov, I. V., Britvin, S. N., Koshlyakova, N. N., Vigasina, M. F., and Sidorov, E. G.: A new mineral ferrisanidine, $\mathrm{K}\left[\mathrm{Fe}^{3+} \mathrm{Si}_{3} \mathrm{O}_{8}\right]$, the first natural feldspar with species-defining iron, Minerals, 9, 770, https://doi.org/10.3390/min9120770, 2019.

Shchipalkina, N. V., Pekov, I. V., Britvin, S. N., Koshlyakova, N. N., and Sidorov, E. G.: Arsenic and phosphorus in feldspar framework: sanidine-filatovite solid-solution series from fumarolic exhalations of the Tolbachik volcano, Kamchatka, Russia, Phys. Chem. Miner., 47, 1, https://doi.org/10.1007/s00269-019-010675, 2020a.
Shchipalkina, N. V., Pekov, I. V., Koshlyakova, N. N., Britvin, S. N., Zubkova, N. V., Varlamov, D. A., and Sidorov, E. G.: Unusual silicate mineralization in fumarolic sublimates of the Tolbachik volcano, Kamchatka, Russia - Part 1: Neso-, cyclo-, ino- and phyllosilicates, Eur. J. Mineral., 32, 101-119, https://doi.org/10.5194/ejm-32-101-2020, 2020b.

Smyth, J. R.: Experimental study on the polymorphism of enstatite, Am. Mineral., 59, 345-352, 1974.

Stewart, D. B. and Wright, T. L.: Al/Si order and symmetry of natural alkali feldspars, and the relationship of strained cell parameters to bulk composition, Bull. Soc. Fr. Mineral. Cr., 97, 356-377, 1974.

Symonds, R. B. and Reed, M. H.: Calculation of multicomponent chemical equilibria in gas-solid-liquid systems: calculation methods, thermochemical data, and applications to studies of high-temperature volcanic gases with examples from Mount St. Helens, Am. J. Sci., 293, 758-864, 1993.

Tachi, T., Horiuchi, H., and Nagasawa, H.: Structure of Cu-bearing orthopyroxene, $\mathrm{Mg}\left(\mathrm{Cu}_{0.56} \mathrm{Mg}_{0.44}\right) \mathrm{Si}_{2} \mathrm{O}_{6}$, and behavior of $\mathrm{Cu}^{2+}$ in the orthopyroxene structure, Phys. Chem. Miner., 24, 463476, 1997.

Thornton, C. P. and Tuttle, O. F.: Chemistry of igneous rocks. I. Differentiation index, Am. J. Sci., 258, 661-681, 1960.

Tropper, P., Recheis, A., and Konzett, J.: Pyrometamorphic formation of phosphorus-rich olivines in partially molten metapelitic gneisses from a prehistoric sacrificial burning site (Otz Valley, Tyrol, Austria), Eur. J. Mineral., 16, 631-640, 2004.

Van Peteghem, J. K. and Burley, B. J.: Studies on solid solution between sodalite, nosean and haüyne, Can. Mineral., 7, 808-813, 1963.

Vergasova, L. P. and Filatov, S. K.: A study of volcanogenic exhalation mineralization, J. Volcanol. Seismol., 10, 71-85, 2016.

Vergasova, L. P., Krivovichev, S. V., Britvin, S. N., Burns, P., and Ananiev, V. V.: Filatovite, $\mathrm{K}[\mathrm{Al}, \mathrm{Zn})_{2}(\mathrm{As}, \mathrm{Si})_{2} \mathrm{O}_{8}$, a new mineral species from the Tolbachik volcano, Kamchatka peninsula, Russia, Eur. J. Mineral., 16, 533-536, 2004.

Zambonini, F.: Mineralogia Vesuviana, Atti R. Ace. Sc. Fis., Mat. Ser. 2, 14/7, 1-463, 1910.

Zelenski, M., Malik, N., and Taran, Yu.: Emissions of trace elements during the 2012-2013 effusive eruption of Tolbachik volcano, Kamchatka: enrichment factors, partition coefficients and aerosol contribution, J. Volcanol. Geoth. Res., 285, 136-149, 2014. 